Article

\title{
Iprodione Removal by UV-Light-, Zero-Valent Iron- and Zero-Valent Aluminium-Activated Persulfate Oxidation Processes in Pure Water and Simulated Tertiary Treated Urban Wastewater
}

\author{
Bahareh Montazeri, Olga Koba-Ucun, Idil Arslan-Alaton * and Tugba Olmez-Hanci
}

check for updates

Citation: Montazeri, B.; Koba-Ucun, O.; Arslan-Alaton, I.; Olmez-Hanci, T Iprodione Removal by UV-Light-, Zero-Valent Iron- and Zero-Valent Aluminium-Activated Persulfate Oxidation Processes in Pure Water and Simulated Tertiary Treated Urban Wastewater. Water 2021, 13, 1679. https://doi.org/10.3390/w13121679

Academic Editors:

Jorge Rodríguez-Chueca,

Miray Bekbolet and Isabella

Natali Sora

Received: 8 March 2021

Accepted: 15 June 2021

Published: 17 June 2021

Publisher's Note: MDPI stays neutral with regard to jurisdictional claims in published maps and institutional affiliations.

Copyright: (c) 2021 by the authors. Licensee MDPI, Basel, Switzerland. This article is an open access article distributed under the terms and conditions of the Creative Commons Attribution (CC BY) license (https:/ / creativecommons.org/licenses/by/ $4.0 /)$.
Department of Environmental Engineering, School of Civil Engineering, Ayazaga Campus, Istanbul Technical University, Maslak, Istanbul 34469, Turkey; montazeri16@itu.edu.tr (B.M.); olgakoba24@gmail.com (O.K.-U.); tolmez@itu.edu.tr (T.O.-H.)

* Correspondence: arslanid@itu.edu.tr

\begin{abstract}
The degradation of iprodione (IPR), a once frequently used but recently banned dicarboximide fungicide, by UV-C light-, zero-valent iron- (ZVI), and zero-valent aluminium (ZVA)-activated persulfate (PS) oxidation processes was comparatively studied in distilled (pure) water (DW) and simulated, tertiary treated urban wastewater (SWW). The performance of PS-activated oxidation processes was examined by following IPR (2-10 mg/L) removal, PS (0.01-1.00 mM) consumption, metal ion release (for the two heterogeneous catalytic oxidation processes), dissolved organic carbon (DOC) removal as well as hydroxylated aromatic and low molecular weight aliphatic degradation products. The effect of $\mathrm{pH}$ and PS concentrations on IPR removal was examined in DW. While the experiments in DW highlighted the superior performance of UV-C/PS treatment (with 78\% DOC removal after $120 \mathrm{~min}$ at $\mathrm{pH}=6.2$ ), the performance of UV-C/PS treatment decreased sharply (to $24 \%$ DOC removal after $120 \mathrm{~min}$ at $\mathrm{pH}=6.8$ ) in the complex wastewater matrix (in SWW). Complete IPR (in $20 \mathrm{~min}$ ) and 40\% DOC (in $120 \mathrm{~min}$ ) removals were obtained with ZVI/PS treatment $(1 \mathrm{~g} / \mathrm{L}$ ZVI, $1.5 \mathrm{mM}$ PS, $\mathrm{pH}=3.0$ ), which was the most effective oxidation process in SWW. The treatment performance was strongly influenced by the SWW constituents, and UV-C/PS treatment appeared to be the most sensitive to it.
\end{abstract}

Keywords: iprodione removal; UV-C-activated persulfate; zero-valent iron-activated persulfate; zero-valent aluminium-activated persulfate; performance in simulated urban wastewater

\section{Introduction}

Hydantoin, or glycolylurea, is a five-membered ring heterocyclic compound with the formula $\mathrm{CH}_{2} \mathrm{C}(\mathrm{O}) \mathrm{NHC}(\mathrm{O}) \mathrm{NH}$ [1]. In a more general sense, hydantoins can refer to groups and a class of compounds with the same ring structure as the parent. In pharmaceuticals, hydantoin derivatives form a class of anticonvulsants: phenytoin and fosphenytoin, both of which contain hydantoin moieties and are both used as anticonvulsants in the treatment of seizure disorders [2]. One of the most important hydantoin derivatives is iprodione (IPR), which has found wide use in agricultural production as a fungicide. IPR is a dicarboximide contact fungicide with protective and curative action. It has a significant role in the control of fungal microorganisms such as Sclerotinia, Botrytis, Rhizoctonia, Alternaria, etc. [3]. In 2011, IPR's global sales reached $\$ 115$ million, accounting for a large proportion of the pesticide market [4].

Recent studies reported the presence of IPR in surface water as well as groundwater, contaminating water sources through the runoff from applied fields and/or groundwater through leaching [5-9]. IPR is a steroidogenesis inhibitor and can cause short- and longterm health effects such as atrophy and hypertrophy [10]. Furthermore, it has been reported that IPR is toxic to aquatic organisms [11], moderately toxic to small animals [12], and 
probably carcinogenic to humans [13]. In 2017, the approval of IPR was not renewed by the European Commission (EC) under EC 2017/2091 [14].

In the last three decades, advanced oxidation processes (AOPs) have been reported extensively for the removal of a wide range of micropollutants [15-18]. These processes mainly involve hydroxyl radicals $\left(\mathrm{HO}^{\bullet}\right)$ and sulfate radicals $\left(\mathrm{SO}_{4}{ }^{\bullet-}\right)$ that can transform micropollutants into less harmful degradation intermediates and/or eventually mineralize them. Under appropriate conditions, AOPs can oxidize biologically resistant, toxic, and/or recalcitrant pollutants through the intermediacy of reactive oxygen species [19] though the potential formation of toxic, poor, and partial mineralization products and can be considered as a serious limitation associated with AOPs $[19,20]$. AOPs generally involve $\mathrm{O}_{3}, \mathrm{H}_{2} \mathrm{O}_{2}$, and persulfate (PS) as oxidants with the assistance of UV light [16], catalysts [21], ultrasonic insertion [22], and thermal input [23]. $\mathrm{SO}_{4}{ }^{\bullet-}$ is mostly generated via two precursor salts named PS and/or peroxymonosulfate (PMS) [18] and possesses equal or even higher redox potential than $\mathrm{HO}^{\bullet}$ as well as a longer half-life [24,25].

$\mathrm{SO}_{4}{ }^{\bullet-}$ can be generated through the UV-C activation of PS wherein one mole of PS undergoes UV-C photolysis and is cleaved into two moles of $\mathrm{SO}_{4}{ }^{--}$through the following equation [26];

$$
\mathrm{S}_{2} \mathrm{O}_{8}{ }^{2-}+h v \rightarrow 2 \mathrm{SO}_{4} \cdot-
$$

Recently, catalytic activation of PS for $\mathrm{SO}_{4}{ }^{--}$production has been reported as an advanced oxidation process to alternatively reduce toxicity and/or increase the biodegradability of wastewater [27-31]. Particularly, zero-valent iron (ZVI) and zero-valent aluminium (ZVA) activation methods have been applied to remove micropollutants from aqueous solutions [21,32]. ZVI is an effective activator of PS because of its high reactivity (reduction potential $=-0.44 \mathrm{~V}$ vs. SHE). ZVA has also gained some attention because of its higher redox potential than ZVI (reduction potential $=-1.67 \mathrm{~V}$ vs. SHE) to activate oxidants, including peroxides, for the degradation of a variety of contaminants in aqueous solutions [32]. The peroxide PS can be activated by ZVI (2-5) and ZVA (6) nanoparticles through the following redox reactions taking place at the metal surface as well as solution bulk [33-35];

$$
\begin{gathered}
\mathrm{Fe}^{0}+\mathrm{S}_{2} \mathrm{O}_{8}{ }^{2-} \rightarrow \mathrm{Fe}^{2+}+2 \mathrm{SO}_{4}{ }^{2-} \\
\mathrm{Fe}^{2+}+\mathrm{S}_{2} \mathrm{O}_{8}{ }^{2-} \rightarrow \mathrm{Fe}^{3+}+\mathrm{SO}_{4}{ }^{2-}+\mathrm{SO}_{4}{ }^{\bullet-} \\
\mathrm{Fe}^{0}+\mathrm{S}_{2} \mathrm{O}_{8}{ }^{2-} \rightarrow \mathrm{Fe}^{2+}+2 \mathrm{SO}_{4}{ }^{2-}+2 \mathrm{SO}_{4}{ }^{\bullet-} \\
\mathrm{Fe}_{\left(\text {surf }^{2+}\right.}{ }^{2+} \mathrm{S}_{2} \mathrm{O}_{8}{ }^{2-} \rightarrow \mathrm{Fe}_{(\text {surf }}{ }^{3+}+\mathrm{SO}_{4}{ }^{2-}+\mathrm{SO}_{4}{ }^{\bullet-} \\
2 \mathrm{Al}^{0}+\mathrm{S}_{2} \mathrm{O}_{8}{ }^{2-}+6 \mathrm{H}^{+}+1.5 \mathrm{O}_{2} \rightarrow 2 \mathrm{SO}_{4}{ }^{\bullet-}+3 \mathrm{H}_{2} \mathrm{O}
\end{gathered}
$$

Considering the above-mentioned urgent need for an effective treatment alternative to eliminate harmful industrial micropollutants from water/wastewater, the present study aimed at investigating the potential of one homogenous photochemical (UV-C-based) and to heterogeneous catalytic (zero-valent metal-based) PS activation processes for IPR removal from pure water and synthetic tertiary treated wastewater. These different types of oxidation systems were selected since photochemical AOPs offer the inherent advantage of highly efficient at targeting pollutants and organic carbon removal, whereas heterogeneous catalytic processes would enable catalyst separation and multiple use in real treatment applications though mass-transfer limitations would also be expected. In the first part of this study, IPR removal was examined in pure water (distilled water; DW) at varying PS concentrations and $\mathrm{pH}$ values employing different PS activation methods so as to optimize these processes. The treatment performances were comparatively evaluated in terms of major parameters such as IPR removal, PS consumption, and metal ion $(\mathrm{Fe}, \mathrm{Al})$ release. Furthermore, degradation products of IPR were examined by liquid chromatography (LC) for all of the studied treatment processes. Owing to the fact that the presence of different water constituents (organic as well as inorganic substances) in the reaction solution may dramatically affect the treatment performance of both homogenous photochemical and 
heterogeneous catalytic oxidation processes, it is of major importance to carefully examine their performance prior to real wastewater treatment applications. Therefore, in the second part of study, UV-C/PS, ZVI/PS, and ZVA/PS processes were applied in simulated tertiary treated urban wastewater (SWW) spiked with IPR under selected/optimized treatment conditions.

\section{Materials and Methods}

\subsection{Materials}

IPR was purchased from Sigma-Aldrich (purity $>98 \%$ ) (Darmstadt, Germany) and used as received. Potassium persulfate (formula: $\mathrm{K}_{2} \mathrm{~S}_{2} \mathrm{O}_{8}$; molecular weight: $270 \mathrm{~g} / \mathrm{mol}$ ), hydroquinone (formula: $\mathrm{C}_{6} \mathrm{H}_{6} \mathrm{O}_{2} ;$ molecular weight:110 g/mol), benzoquinone (formula: $\mathrm{C}_{6} \mathrm{H}_{4} \mathrm{O}_{2}$; molecular weight:108 $\mathrm{g} / \mathrm{mol}$ ), phenol (formula: $\mathrm{C}_{6} \mathrm{H}_{6} \mathrm{O}$; molecular weight: $94 \mathrm{~g} / \mathrm{mol}$ ), 4-chlorophenol (4-CP), 2,4-dichloroaniline (2,4-DCA), and phthalic acid (formula: $\mathrm{C}_{8} \mathrm{H}_{6} \mathrm{O}_{4} ;$ molecular weight: $166 \mathrm{~g} / \mathrm{mol}$ ) were purchased from Sigma-Aldrich. Lactic acid (formula: $\mathrm{C}_{3} \mathrm{H}_{6} \mathrm{O}_{3}$; molecular weight: $90 \mathrm{~g} / \mathrm{mol}$ ), acetic acid (formula: $\mathrm{C}_{2} \mathrm{H}_{4} \mathrm{O}_{2}$; molecular weight: $60 \mathrm{~g} / \mathrm{mol}$ ), and formic acid (formula: $\mathrm{CH}_{2} \mathrm{O}_{2} ;$ molecular weight: $46 \mathrm{~g} / \mathrm{mol}$ ) were purchased from Merck. Catechol (formula: $\mathrm{C}_{6} \mathrm{H}_{6} \mathrm{O}_{2} ;$ molecular weight: $110 \mathrm{~g} / \mathrm{mol}$ ) was obtained from Acros Organics. Methanol, acetic acid, sulfuric acid, and LC-MS grade water for mobile phase preparation were supplied to prepare the HPLC mobile phase. Commercial nano-scale ZVI (average particle size $50 \mathrm{~nm}$; BET surface area $20-25 \mathrm{~m}^{2} / \mathrm{g}$; purity $>99.5 \%$ ) was obtained from Nanofer Star, Nano Iron (Czech Republic). High purity (>99.5\%) ZVA nanoparticles (average particle size $100 \mathrm{~nm}$; specific surface area $10-20 \mathrm{~m}^{2} / \mathrm{g}$ ) were purchased from US Research Nanomaterials, Inc. (Houston, TX, USA). All aqueous solutions were prepared in DW. In the second part of this study, the treatment performances of the UV-C/PS, ZVI/PS, and ZVA/PS processes were examined under more realistic treatment conditions, with IPR added into SWW, simulating a tertiary treated urban effluent. The composition/preparation of the SWW has been described in detail elsewhere [36].

\subsection{Experimental Procedures}

The UV-C/PS experiments were conducted in a LZC-ORG model (Luzchem Research Inc., Gloucester, ON, Canada) photochemical reaction chamber (dimensions: $32 \times 33 \times 21 \mathrm{~cm}$ ). The photoreactor set-up and experimental procedure of the UV-C/PS are given elsewhere in detail [36]. The average radiation flux of the UV-C lamps (UV-C intensity) was measured as $0.5 \mathrm{~W} / \mathrm{L}$ by a radiometer incorporated into the reaction chamber. The UV-C/PS experiments were conducted at the natural $\mathrm{pH}$ values of pure water and synthetic wastewater $(\approx 6-7)$ without $\mathrm{pH}$ adjustment due to the fact that according to our previous studies, this particular $\mathrm{pH}$ was suitable for UV-C/PS treatment, and avoiding $\mathrm{pH}$ adjustment is a more realistic way to treat tertiary urban effluent [36-38]. All of the ZVI/PS and ZVA/PS experiments were carried out in $500 \mathrm{~mL}$-capacity borosilicate glass beakers under continuous stirring at $150 \mathrm{rpm}$ to maintain the oxygen concentration of the reaction solution near saturated levels and to distribute ZVI and ZVA particles properly in the reaction solution. Experiments were carried out with $2 \mathrm{mg} / \mathrm{L}$ and $10 \mathrm{mg} / \mathrm{L}$ IPR in DW. Although this IPR concentration is much higher than environmentally relevant micropollutant concentrations reported in the scientific literature $[39,40]$, this concentration was chosen to ensure accurate analytical, kinetic, and toxicological measurements. Furthermore, since most treatability studies dealing with the advanced oxidation of micropollutants such as IPR were conducted in the "mg/L" (ppm) concentration range, working with $\mathrm{mg} / \mathrm{L}$ concentrations would enable the comparison of the present experimental results with previous related work [7,41-44]. Prior to ZVI/PS and ZVA/PS experiments, the initial pH values of the reaction solutions were adjusted to the desired, acidic value by adding $1-4 \mathrm{~N} \mathrm{H}_{2} \mathrm{SO}_{4}$. The selection of the acidic $\mathrm{pH}$ conditions for zero-valent metal-activated PS oxidation was based on former related studies in which more effective treatment performances of heterogeneous Fenton/Fenton-like reactions were reported under acidic $\mathrm{pH}(=2-5)$ conditions and with $1 \mathrm{~g} /$ catalyst concentration [21,45,46]. Therefore, after $\mathrm{pH}$ adjustment, $1 \mathrm{~g} / \mathrm{L}$ of 
ZVI (or $1 \mathrm{~g} / \mathrm{L}$ of ZVA) was added to the reaction solution, and finally, PS was introduced to start reaction. Samples were taken at regular time intervals and filtered through $0.22 \mu \mathrm{m}$ PVDF syringe filters (GVS, USA) to remove ZVI (or ZVA) particles. Additionally, the $\mathrm{pH}$ of the samples was increased to 7.0 by adding 1-4 $\mathrm{N} \mathrm{NaOH}$ to remove the formed ferric hydroxide flocs and stop Fenton/Fenton-like reactions [21,47]. For the quantitative LC analyses, experiments were conducted in pure water (DW) with $10 \mathrm{mg} / \mathrm{L} \mathrm{IPR.}$

\subsection{Analytical and Instrumental Procedures}

IPR and its degradation products were monitored with a high-performance liquid chromatography (HPLC; Agilent 1100 Series, Agilent Technologies, Santa Clara, CA, USA) coupled with a diode array detector (G1315A, Agilent Series). IPR, 4-CP, and 2,4-DCA measurements were done at $210 \mathrm{~nm}, 280$ and $240 \mathrm{~nm}$, respectively, with a Nova-Pak C18 (3.9 mm $\times 150 \mathrm{~mm}, 4 \mu \mathrm{m}$, Waters, Milford, MA, USA) reversed phase column. The mobile phase consisted of $70 \% v / v$ methanol and $30 \% v / v$ ultra-pure water at a flow rate of $1 \mathrm{~mL} / \mathrm{min}$. The injection volume in the HPLC analysis and the temperature of the column were set as $100 \mu \mathrm{L}$ and $25^{\circ} \mathrm{C}$, respectively. IPR detection and quantification limits were determined as $0.03 \mathrm{mg} / \mathrm{L}$ and $0.10 \mathrm{mg} / \mathrm{L}$, respectively. Analytical conditions for the determination of hydroxylated degradation products of IPR including phenol, hydroquinone, $p$-benzoquinone, catechol, and phthalic acid were the following: 79.2\% $v / v$ ultrapure water, $19.8 \% v / v$ methanol, and $1.0 \% v / v$ acetic acid run at a flow rate of $0.8 \mathrm{~mL} / \mathrm{min}$ at $270 \mathrm{~nm}, 290 \mathrm{~nm}, 245 \mathrm{~nm}, 276 \mathrm{~nm}$, and $254 \mathrm{~nm}$ for phenol, hydroquinone, p-benzoquinone, catechol, and phthalic acid qualifications, respectively. The HPLC column temperature and injection volume were set as $40{ }^{\circ} \mathrm{C}$ and $40 \mu \mathrm{L}$, respectively. The IPR concentration was elevated from $2 \mathrm{mg} / \mathrm{L}$ to $10 \mathrm{mg} / \mathrm{L}$ during the investigation of IPR degradation products to facilitate analytical/instrument procedures.

In order to measure the released Fe and Al during the ZVI/PS and ZVA/PS treatments, 40-mL sample aliquots were taken at regular time intervals for $120 \mathrm{~min}$, filtered through $0.22 \mu \mathrm{m}$ PVDF syringe filters, and quenched immediately by adding $2 \mathrm{~mL}$ of freshly prepared sodium sulphite $\left(\mathrm{Na}_{2} \mathrm{SO}_{3} ; 10 \% w / v\right.$ solution). Fe and Al were measured on a Perkin-Elmer ICP-MS (USA). For carboxylic acids (acetic acid, formic acid, and lactic acid) evolving during IPR treatment, the quantitative analysis was carried out with a Prominence LC-20A series HPLC. The analytical column (SHIM-PACK SCR-101H; $300 \mathrm{~mm} \times 7.9 \mathrm{~mm} \times 10 \mu \mathrm{m}$ ) was maintained at $60^{\circ} \mathrm{C}$ and the mobile phase was $0.025 \%$ $v / v \mathrm{H}_{2} \mathrm{SO}_{4}$ run at a flow rate of $0.7 \mathrm{~mL} / \mathrm{min}$ [48]. The dissolved (DOC) and total organic carbon (TOC) content of the samples was measured on a Shimadzu VPCN analyzer (Japan) equipped with an autosampler. Residual PS concentrations were determined by employing a colorimetric method [49] using a Jenway 6300 spectrophotometer (UK).

\section{Results}

\subsection{Effect of PS Concentration}

Preliminary experiments (UV-C/PS, ZVI/PS, ZVA/PS) carried out in DW spiked with $2 \mathrm{mg} / \mathrm{L}$ IPR indicated that even UV-C photolysis (UV-C intensity $=0.5 \mathrm{~W} / \mathrm{L}$; without PS addition) was capable of almost complete IPR removal ( $\approx 97 \%)$ after 120 min (Figure 1$)$. As seen in Figure 1, the addition of PS $(0.01-0.100 \mathrm{mM})$ enhanced IPR removal at all of the studied PS concentrations due to its activation by UV-C light. This increase in IPR removal can be attributed to the presence of more $\mathrm{SO}_{4}{ }^{\bullet-}$ that were photochemically generated at higher rates in the reaction solution upon elevation of PS concentrations. According to Figure 1, upon the addition of $0.03 \mathrm{mM}$ PS to the reaction solution, IPR removal rates were significantly enhanced, resulting in complete IPR after 20 min of treatment. With the highest examined initial PS concentration of $0.100 \mathrm{mM}$ PS, the time for complete IPR removal by UV-C/PS was reduced to $2 \mathrm{~min}$. In other words, removal rates increased with increasing PS concentrations, and no inhibitory effects due to excessive ("overdosed") PS concentrations were observed in the studied PS concentration range due to the fact that relatively low PS concentrations were used in this work. 


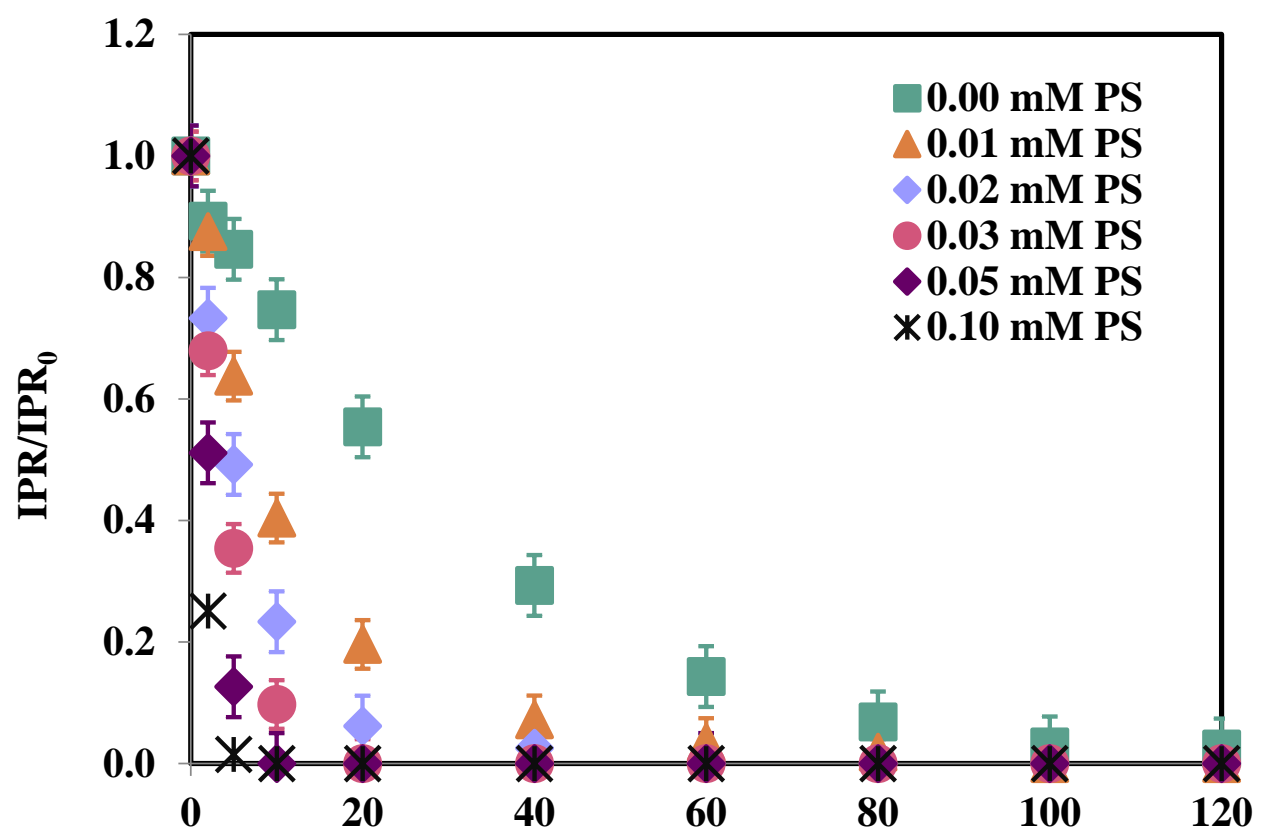

Time (min)

Figure 1. Changes in normalized IPR concentrations during UV-C and UV-C/PS treatments in DW at varying initial PS concentrations. IPR $=2 \mathrm{mg} / \mathrm{L} ; \mathrm{UV}-\mathrm{C}$ intensity $=0.5 \mathrm{~W} / \mathrm{L} ; \mathrm{pH}=6.2$.

For the heterogeneous catalytic experiments, several "control" experiments were also carried out in the absence of PS $(\mathrm{ZVI}=1 \mathrm{~g} / \mathrm{L} ; \mathrm{ZVA}=1 \mathrm{~g} / \mathrm{L})$ or zero-valent metals (with PS $=1.00 \mathrm{mM}$ only) at an initial concentration of $2 \mathrm{mg} / \mathrm{L}$ IPR in DW to explore IPR degradation without the activation of zero-valent metal particles or directly with PS, respectively (See Table S1). The obtained results indicated that with mere ZVI at an initial $\mathrm{pH}$ of 5.0 and mere ZVA at an initial $\mathrm{pH}$ of 3.0, IPR removals were limited to practically no removal and $35 \%$, respectively, after $120 \mathrm{~min}$ of treatment (Figure 2). This observation was attributable to the higher redox potential of ZVA compared to ZVI as mentioned in the introduction section. However, it should be noted here that high reactivity (less selectivity) of ZVA compared to ZVI may be a disadvantage when working in real wastewater due to the fact that a more reactive oxidation system will more readily react with the wastewater components, causing competition reactions with the target pollutant and decreasing its removal efficiency $[50,51]$.

Similarly, incomplete IPR removal was observed after 120 min with mere PS oxidation (data not shown), revealing that the degradation of IPR with PS was not significant and highlighting the role of ZVI or ZVA activation of PS for effective IPR removal by oxidation. Limited pollutant removals have already been reported in previous studies through the absence of catalyst or oxidant functioning as activators and/or mediators of free radical chain reactions [30,31,52-54]. For example, Zhao et al. [52], who investigated bisphenol A (BPA) removal $(22 \mu \mathrm{M})$ at initial $\mathrm{pH}$ of 6.0 by mere PS $(0.1 \mathrm{~g} / \mathrm{L} \mathrm{ZVI})$ and mere ZVI $(0.2 \mathrm{mM}$ PS) [52]. In their study, control experiments in the absence of ZVI or PS were conducted, and no BPA removal was obtained for the controls, indicating ZVI or PS alone could not cause BPA degradation. 


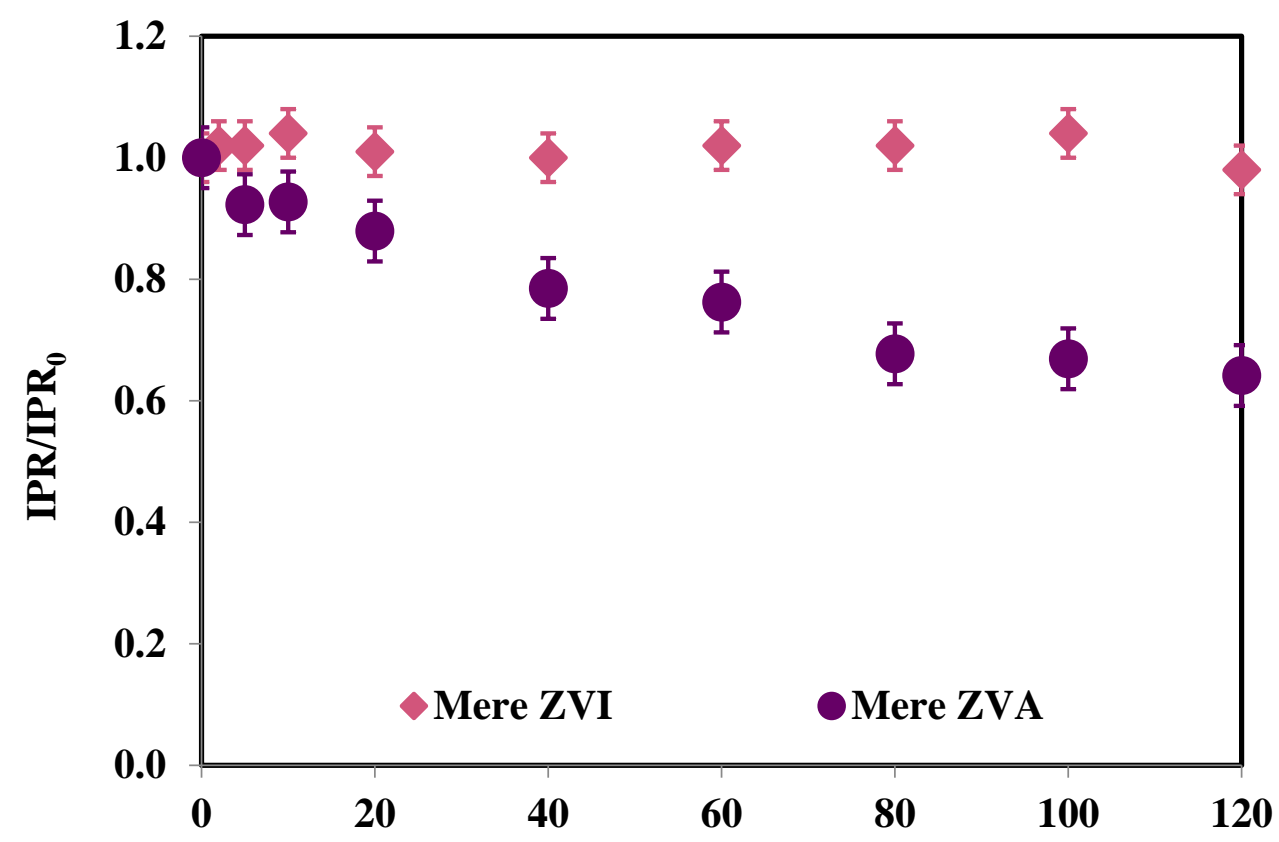

Time (min)

Figure 2. Changes in normalized IPR concentrations during mere ZVI treatment at an initial $\mathrm{pH}$ of 5.0 and mere ZVA treatment at an initial $\mathrm{pH}$ of 3.0. IPR $=2 \mathrm{mg} / \mathrm{L} ; \mathrm{ZVI}=1 \mathrm{~g} / \mathrm{L} ; \mathrm{ZVA}=1 \mathrm{~g} / \mathrm{L}$.

Figure 3 depicts the effect of initial PS concentration in the range of $0.10-1.00 \mathrm{mM}$ on normalized IPR removals during ZVI/PS treatment $(\mathrm{pH}=5.0)$. As seen in Figure 3, practically no IPR removal $(<5 \%)$ was observed after $120 \mathrm{~min}$ of ZVI/PS treatment in the low PS concentration range of $0.10 \mathrm{Mm}-0.25 \mathrm{mM}$. However, upon increasing the initial PS concentrations to $0.50 \mathrm{mM}$ and $0.75 \mathrm{mM}$, complete IPR removal was achieved for both examined PS concentrations after $120 \mathrm{~min}$ of ZVI/PS treatment (see Table S2 for more details and comparison with $\mathrm{pH}=3.0$ ). Eventually, as the initial PS concentration was increased from $0.75 \mathrm{mM}$ to $1.00 \mathrm{mM}$, the time required for complete IPR degradation decreased from $120 \mathrm{~min}$ to $80 \mathrm{~min}$, revealing that a higher PS concentration favored IPR degradation. This could be ascribed to an increase in $\mathrm{SO}_{4}{ }^{\bullet-}$ production. This was consistent with the study reported by Wu et al. [30], who examined the performance of ZVI/PS and the effects of initial PS concentration ( $0.2 \mathrm{mM}-2.5 \mathrm{mM}$ PS) on atrazine removal. In that study, the degradation of $10 \mathrm{mg} / \mathrm{L}$ atrazine was affected by the PS concentration and after increasing the initial PS concentration from $0.2 \mathrm{mM}$ to $0.4 \mathrm{mM}$, the atrazine removal appreciably increased from $34 \%$ to $80 \%$. However, an inhibitory effect was evidenced at higher initial PS concentrations (1.0 $\mathrm{mM}$ and $2.5 \mathrm{mM} \mathrm{PS})$, which was attributed to the generation of more $\mathrm{SO}_{4}{ }^{\bullet-}$ and its self-consumption, so excessive concentrations of PS lead to decreased atrazine removals [30]. The effect of the initial PS concentration on metoprolol, a common drug used to cure cardiovascular diseases, was investigated in the range of $0.25 \mathrm{mM}-4.00 \mathrm{mM}$ PS. In that study, the degradation of metoprolol increased from $40.2 \%$ to $96.3 \%$ as the PS concentration was increased from $0.50 \mathrm{mM}$ to $3.00 \mathrm{mM}$. However, with a further increment of the initial PS concentration up to $4.00 \mathrm{mM}$, no change in metoprolol degradation was observed, probably due to the side reaction between $\mathrm{SO}_{4}{ }^{\bullet-}$ and excess $\mathrm{PS}$ and the self-combination of $\mathrm{SO}_{4}{ }^{\circ-}$, causing minor improvement during the treatment process [31]. 


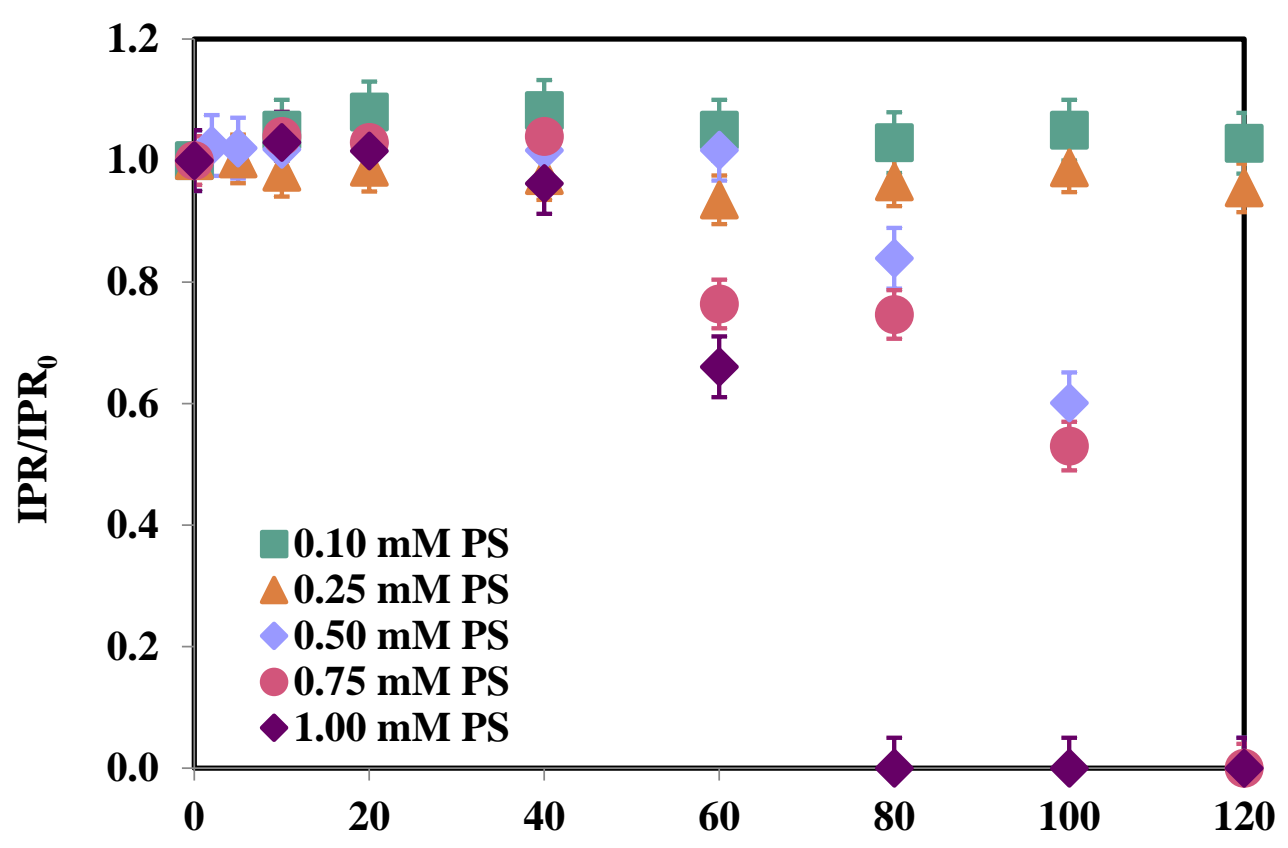

Time (min)

Figure 3. Changes in normalized IPR concentration during ZVI/PS treatments in DW at varying initial PS concentrations. IPR $=2 \mathrm{mg} / \mathrm{L} ; \mathrm{ZVI}=1 \mathrm{~g} / \mathrm{L} ; \mathrm{pH}=5.0$.

The effect of initial PS concentration in the range of $0.10 \mathrm{mM}-1.00 \mathrm{mM}$ PS on IPR removal rates was also examined during ZVA/PS treatment at an initial $\mathrm{pH}$ of 3.0 and presented in Figure 4 (see Table S3 for more details and comparison with $\mathrm{pH}=1.5$ ). As seen from Figure 4, IPR removal efficiencies obtained after $120 \mathrm{~min}$ ZVA/PS treatment with $0.10 \mathrm{mM}$ and $0.25 \mathrm{mM}$ PS were almost $80 \%$. Upon increasing the initial PS concentration to $0.50 \mathrm{mM}$ and $1.00 \mathrm{mM}$, complete IPR removal was observed after $120 \mathrm{~min}$ of treatment. This enhancement in IPR removal could be attributed to the generation of more $\mathrm{SO}_{4}{ }^{\bullet-}$, and the initial PS concentration of $1.00 \mathrm{mM}$ was probably not high enough to trigger $\mathrm{SO}_{4}{ }^{\bullet-}$ scavenging reactions in the presence of excessive PS. Hence, no reduction in IPR removals were evident with increasing PS concentrations, as they had been for the UVC/PS treatment process. Similarly, in former related work [35], the removal of $2 \mathrm{mg} / \mathrm{L}$ aqueous iopamidol solutions was examined by ZVA/PS at an initial $\mathrm{pH}$ of 3 in DW. In that work, the overall iopamidol removals increased from $75 \%$ for $0.25 \mathrm{mM}$ and $95 \%$ for $0.50 \mathrm{mM}$ treatments upon addition of $1 \mathrm{~g} / \mathrm{L} \mathrm{ZVA}$ at $\mathrm{pH}$ 3.0.

In another related study, the effect of PS concentration $(0.20-4.00 \mathrm{mM})$ on $26.28 \mathrm{mg} / \mathrm{L}$ trichloroethylene removal through ZVA/PS was explored [55]. In that study, experimental findings revealed that the rate constants calculated for trichloroethylene were enhanced progressively from $0.0034 \mathrm{~min}^{-1}$ to $0.0395 \mathrm{~min}^{-1}$ by increasing the PS concentrations from $0.20 \mathrm{mM}$ to $2.00 \mathrm{mM}$. However, the rate constants of trichloroethylene removal decreased upon further increase of the initial PS concentration due to scavenging of $\mathrm{SO}_{4}{ }^{\bullet-}$ by the excessive concentration of PS that might consume the abundant $\mathrm{SO}_{4}{ }^{--}$generated through the following equations [55] and inhibit trichloroethylene removal:

$$
\begin{gathered}
\mathrm{S}_{2} \mathrm{O}_{8}{ }^{2-}+\mathrm{SO}_{4}{ }^{\bullet-} \rightarrow \mathrm{S}_{2} \mathrm{O}_{8}{ }^{\bullet-}+\mathrm{SO}_{4}{ }^{2-} \\
\mathrm{SO}_{4}{ }^{\bullet-}+\mathrm{SO}_{4}{ }^{\bullet-} \rightarrow \mathrm{S}_{2} \mathrm{O}_{8}{ }^{2-} \\
\mathrm{SO}_{4}{ }^{--}+\mathrm{H}_{2} \mathrm{O} \rightarrow \mathrm{SO}_{4}{ }^{2-}+\mathrm{HO}^{\bullet}+\mathrm{H}^{+}
\end{gathered}
$$




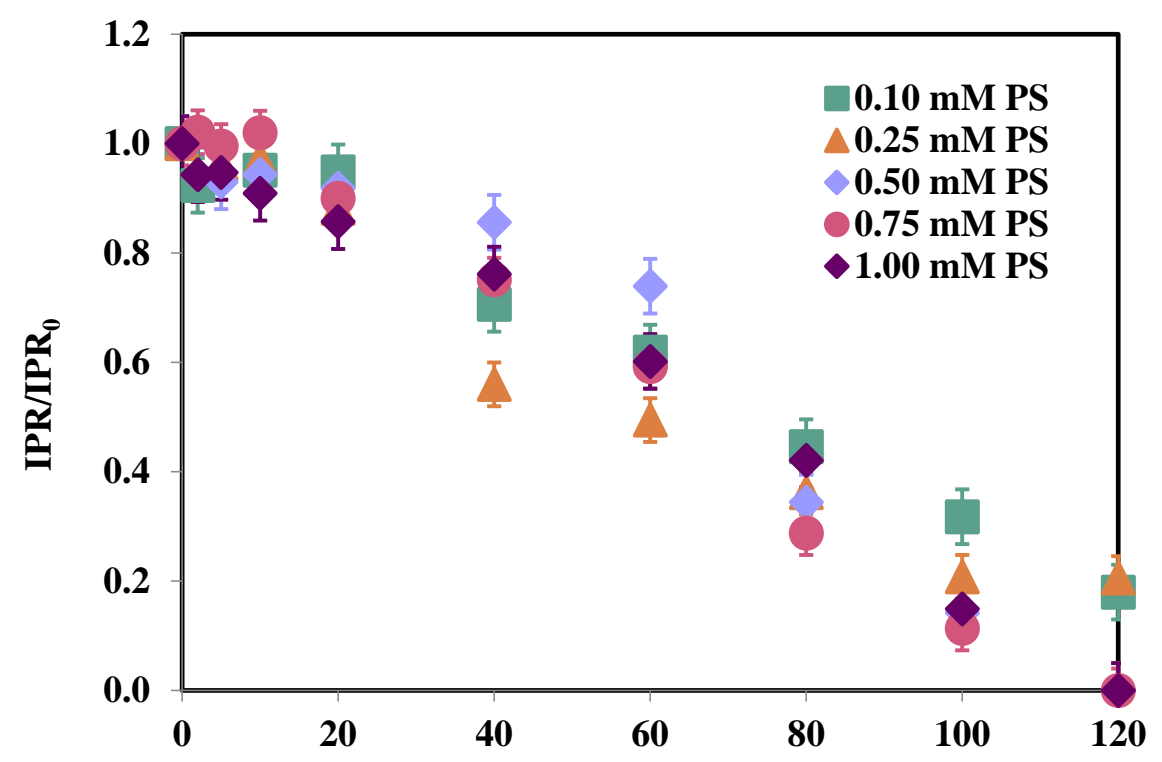

Time (min)

Figure 4. Changes in normalized IPR concentration during ZVA/PS treatments in DW at varying initial PS concentrations. IPR $=2 \mathrm{mg} / \mathrm{L} ; \mathrm{ZVA}=1 \mathrm{~g} / \mathrm{L} ; \mathrm{pH}=3.0$.

In summary, no $\mathrm{SO}_{4}{ }^{\bullet-}$ scavenging effects (excessive/"overdosed" PS concentrations) were observed for the examined PS concentration ranges under the present experimental conditions.

\subsection{Effect of $p H$}

Solution $\mathrm{pH}$ can affect the efficiency of homogenous photochemical and heterogeneous catalytic AOPs remarkably, particularly those involving metals/metal ions/ oxides $[32,35,50,56,57]$. In the present study, no $\mathrm{pH}$ adjustment was carried out for the UV-C/PS treatment since in our former work, the photochemical oxidation of IPR was efficient at around neutral $\mathrm{pH}$ values [36-38]. In previous studies, it was demonstrated that $\mathrm{pH}$ affects the ZVI/PS treatment performance in the degradation of contaminants due to its catalytic activity, formation, and type of dissolved Fe species [58,59]. An acidic $\mathrm{pH}$ environment $(\mathrm{pH} \leq 5)$ could intensively promote the ZVI/PS system $[31,45,46,60]$, most probably due to the accelerated ZVI corrosion that facilitates $\mathrm{Fe}^{2+}$ formation. In order to investigate the $\mathrm{pH}$ effect on IPR degradation during ZVI/PS treatment, $\mathrm{pH}$ values of 3.0 and 5.0 and a PS concentration of $0.50 \mathrm{mM}$ were selected as shown in Figure 5 (see also Table S2). From Figure 5, it is obvious that complete IPR removal was obtained after $10 \mathrm{~min}$ of ZVI/PS treatment at the initial $\mathrm{pH}$ of 3.0, while no IPR removal was observed even after $60 \mathrm{~min}$ of treatment at the initial $\mathrm{pH}$ of 5.0. With the progress of treatment, IPR removal reached $16 \%$ and $40 \%$ after $80 \mathrm{~min}$ and $100 \mathrm{~min}$, respectively, at $\mathrm{pH} 5.0$. As is also evident in Figure 5, complete IPR removal was obtained after $120 \mathrm{~min}$ of ZVI/PS treatment at an initial $\mathrm{pH}$ of 5.0. Thus, it was concluded that IPR removals were enhanced remarkably when the $\mathrm{pH}$ was decreased from 5.0 to 3.0 during ZVI/PS treatment because a more acidic $\mathrm{pH}$ led to a more rapid corrosion of $\mathrm{ZVI}$ and $\mathrm{Fe}^{2+}$ release, resulting in faster as well as more intensive $\mathrm{SO}_{4}{ }^{\bullet-}$ generation [31,60]. The results were in agreement with Goa et al. [31], who studied ZVI/PS treatment of metoprolol in the $\mathrm{pH}$ range of 3.0-11.0. In that study, the maximum degradation efficiency of $99.5 \%$ was achieved at $\mathrm{pH}=3$ and almost $88.7 \%$ metoprolol had degraded within the first $5 \mathrm{~min}$. By increasing the $\mathrm{pH}$ from 5 to 9 , the degradation of metoprolol decreased from $95.9 \%$ to $83.8 \%$ [31].

Since acidic $\mathrm{pH}$ conditions facilitate the removal of organic pollutants and are essential for metal-based catalytic treatment processes $[32,35,50,61,62]$, the $\mathrm{pH}$ values of 3.0 and 
1.5 were tested for the ZVA/PS treatment system (with $0.50 \mathrm{mM}$ PS). Figure 6 depicts the effect of the initial $\mathrm{pH}$ on IPR degradation with ZVA/PS at an initial PS concentration of $0.50 \mathrm{mM}$ (see also Table S3). As apparent from Figure 6, IPR degradation was appreciably faster at $\mathrm{pH}=1.5$ compared to $\mathrm{pH}=3.0$ during the first $60 \mathrm{~min}$ of $\mathrm{ZVA} / \mathrm{PS}$ treatment. This was attributed to the fact that the reactivity of $Z V A$ might be enhanced through the rapid corrosion of ZVA, and the continuous activation of the passive layer in the solution with a higher $\mathrm{H}^{+}$concentration $(\mathrm{pH}=1.5)$ [50]. However, with the progress of the treatment (after $60 \mathrm{~min}$ ), both treatments resulted in similar IPR removal rates.

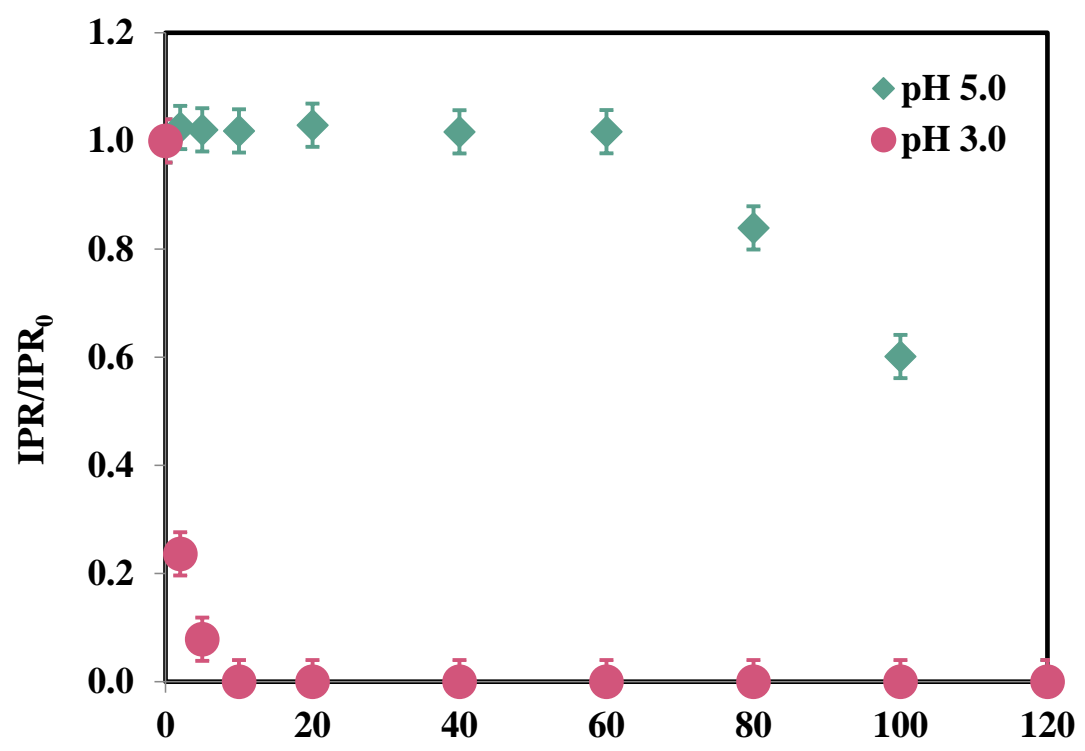

Time (min)

Figure 5. Changes in normalized IPR concentration during ZVI/PS treatments in DW at varying initial $\mathrm{pH}$ values. $\mathrm{IPR}=2 \mathrm{mg} / \mathrm{L} ; \mathrm{PS}=0.50 \mathrm{mM} ; \mathrm{ZVI}=1 \mathrm{~g} / \mathrm{L}$.

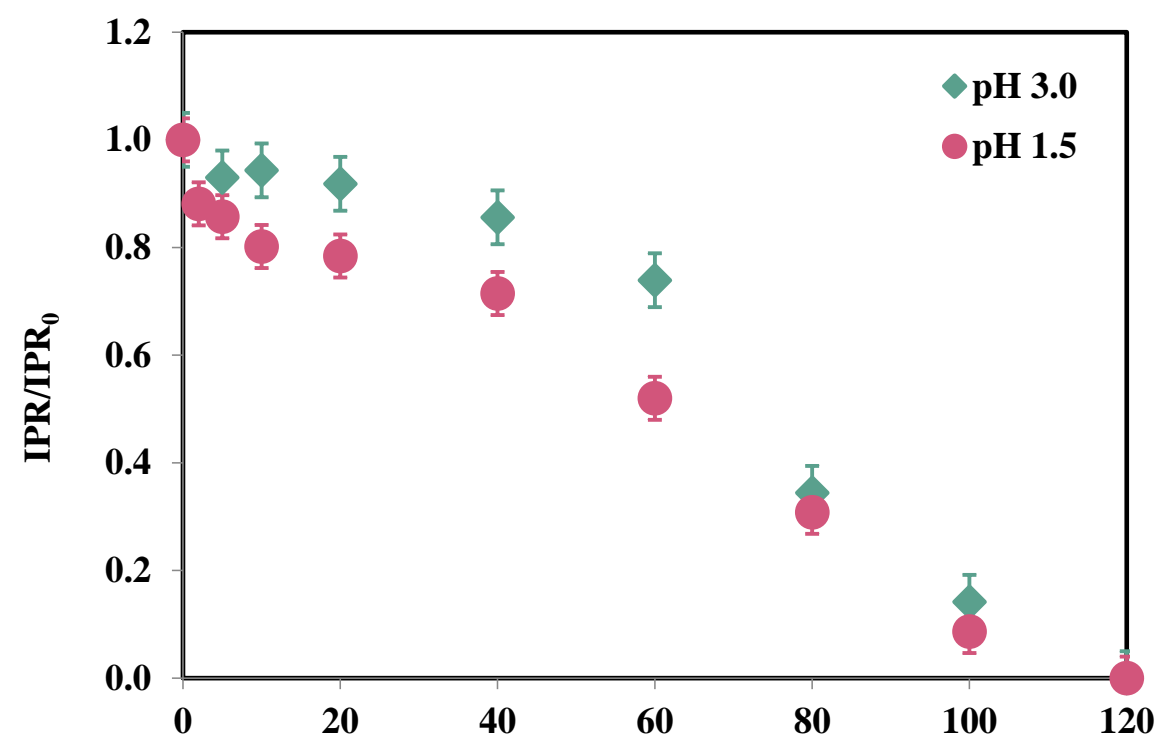

\section{Time (min)}

Figure 6. Changes in normalized IPR concentration during ZVA/PS treatments in DW at varying initial $\mathrm{pH}$ values. IPR $=2 \mathrm{mg} / \mathrm{L} ; \mathrm{PS}=0.50 \mathrm{mM} ; \mathrm{ZVA}=1 \mathrm{~g} / \mathrm{L}$. 


\subsection{Metal (Fe, Al) Release and PS Consumption for Heterogeneous Oxidation Processes}

For heterogeneous catalytic oxidation systems, metal ion release and PS consumption were also assessed to further examine their treatment mechanism. The degree of Fe release and PS consumption was followed during the ZVI/PS ( $\mathrm{PS}=0.50 \mathrm{mM}, \mathrm{pH}=3.0$ ) treatment of $2 \mathrm{mg} / \mathrm{L} \mathrm{IPR}$ in DW (see Table S4 for more details). According to Table 1, complete IPR degradation was achieved during the first $10 \mathrm{~min}$ of the ZVI/PS treatment together with $13 \%$ of PS consumption. As also seen in Table 1, more ZVI surface corrosion resulted in more Fe release from the ZVI surface to the reaction bulk and consequently led to a higher PS consumption for $\mathrm{SO}_{4}{ }^{\bullet-}$ generation. The ultimately released Fe concentration was measured as $129 \mu \mathrm{g} / \mathrm{L}$, where almost complete IPR degradation and PS consumption were achieved. Fe concentrations positively correlated with PS consumption and pollutant removals during the ZVI/PS treatment.

Table 1. IPR abatement, Fe release and PS consumption observed during ZVI/PS treatment of IPR. $\mathrm{IPR}=2 \mathrm{mg} / \mathrm{L} ; \mathrm{PS}=0.50 \mathrm{mM} ; \mathrm{ZVI}=1 \mathrm{~g} / \mathrm{L} ; \mathrm{pH}=3.0$.

\begin{tabular}{cccc}
\hline Time $(\mathbf{m i n})$ & IPR $(\mathbf{m g} / \mathrm{L})$ & Fe $(\mu \mathrm{g} / \mathrm{L})$ & PS Consumption $(\%)$ \\
\hline 5 & 0.16 & $<10$ & 10 \\
10 & 0 & $<10$ & 13 \\
30 & 0 & $<10$ & 20 \\
60 & 0 & 88 & 68 \\
120 & 0 & 129 & 95 \\
\hline
\end{tabular}

Table 2 presents the IPR and released $\mathrm{Al}$ concentrations as well as PS consumption during the ZVA/PS ( $\mathrm{PS}=0.50 \mathrm{mM}$; $\mathrm{pH}=3.0$ ) treatment of $2 \mathrm{mg} / \mathrm{L} \mathrm{IPR} \mathrm{in} \mathrm{DW} \mathrm{(see} \mathrm{Table} \mathrm{S5}$ for more details). According to the $\mathrm{Al}$ ion measurements from Table 2, it was evident that fast $\mathrm{Al}$ release being observed throughout the entire IPR treatment period could be attributed to the acidic $\mathrm{pH}$ environment that hindered ZVA passivation so that continuous $\mathrm{SO}_{4}{ }^{\bullet-}$ and $/$ or $\mathrm{HO}^{\bullet}$ formation and subsequent pollutant degradation occurred via Fentonlike redox reactions [51].

Table 2. IPR abatement, Al release, and PS consumption observed during ZVA/PS treatment of IPR. $\mathrm{IPR}=2 \mathrm{mg} / \mathrm{L} ; \mathrm{PS}=0.50 \mathrm{mM} ; \mathrm{ZVA}=1 \mathrm{~g} / \mathrm{L} ; \mathrm{pH}=3.0$.

\begin{tabular}{cccc}
\hline Time $(\mathbf{m i n})$ & IPR $(\mathbf{m g} / \mathrm{L})$ & Al $(\mu \mathrm{g} / \mathrm{L})$ & PS Consumption $(\%)$ \\
\hline 5 & 1.90 & - & - \\
10 & 1.87 & 299 & 5 \\
30 & 1.79 & 324 & 7 \\
60 & 1.49 & 353 & 10 \\
120 & 0 & 499 & 15 \\
\hline
\end{tabular}

\subsection{Degradation Products and Mineralization Rates}

As aforementioned, $\mathrm{SO}_{4}{ }^{\bullet-}$ are generated by the activation of PS with ZVI [63]. Unlike the metal ion activation of PS, where excessive concentrations of ferrous salts are necessary and might even react with $\mathrm{SO}_{4}{ }^{\bullet-}, \mathrm{ZVI}$ can slowly and continuously release ferrous ions to activate PS [63]. In the present study, some IPR degradation products were measured during PS-activated oxidation processes, including ZVI/PS treatment in DW. Figure 7 shows changes in the IPR and DOC (a), hydroquinone (b), carboxylic acids (lactic, acetic acids), and (c) concentrations during the ZVI/PS (PS $=2.50 \mathrm{mM}$ ) treatment of $10 \mathrm{mg} / \mathrm{L} \mathrm{IPR}$ in DW in the initial solution $\mathrm{pH}$ of 3.0. As seen in Figure 7a, almost complete IPR removal was achieved after $20 \mathrm{~min}$ of ZVI/PS treatment. Prolonged ZVI/PS treatment led to only $21 \%$ DOC removal after $120 \mathrm{~min}$, suggesting the formation of intermediates being rather resistant to ultimate oxidation. Formation of 2,4-DCA, 4-CP, catechol, $p$-benzoquinone, phenol, formic acid, and phthalic acid were investigated as possible degradation intermediates during the ZVI/PS treatment of IPR; however, none of them could be detected by LC 
analysis under the selected reaction conditions. Hydroquinone was identified after 90 of $\operatorname{min~ZVI/PS~treatment~as~} 0.44 \mathrm{mg} / \mathrm{L}$, reaching its highest concentration of $0.50 \mathrm{mg} / \mathrm{L}$ after $120 \mathrm{~min}$ of treatment. Acetic and lactic acid at concentrations of $34.3 \mathrm{mg} / \mathrm{L}$ and $16.85 \mathrm{mg} / \mathrm{L}$ could be determined after $20 \mathrm{~min}$ and $40 \mathrm{~min}$ of ZVI/PS treatment, respectively (Figure 7c). Although the concentration of acetic acid gradually increased to $79.6 \mathrm{mg} / \mathrm{L}$ after 120 of min treatment, lactic acid concentration remained practically stable until the end of the treatment.
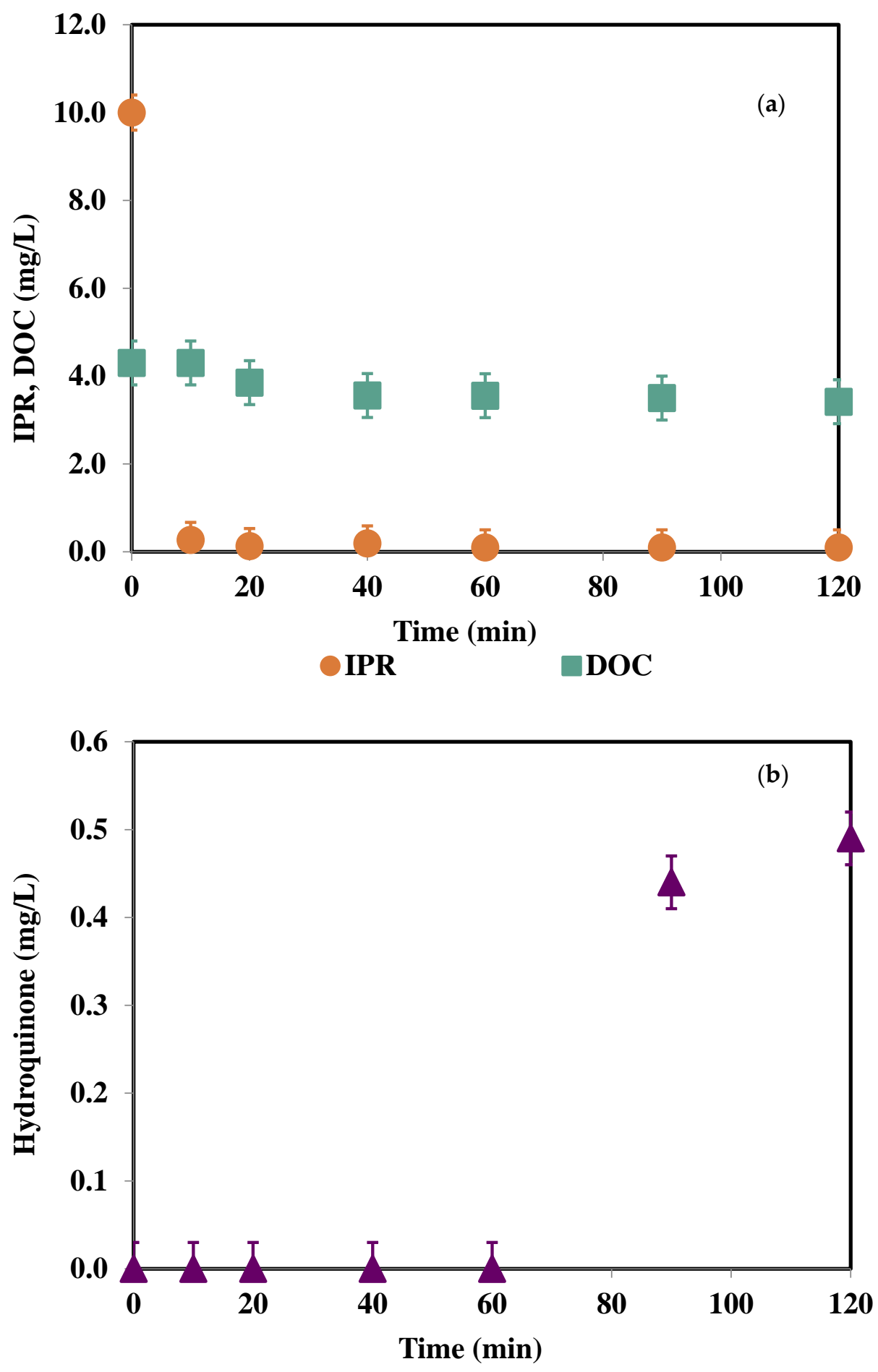

Figure 7. Cont. 


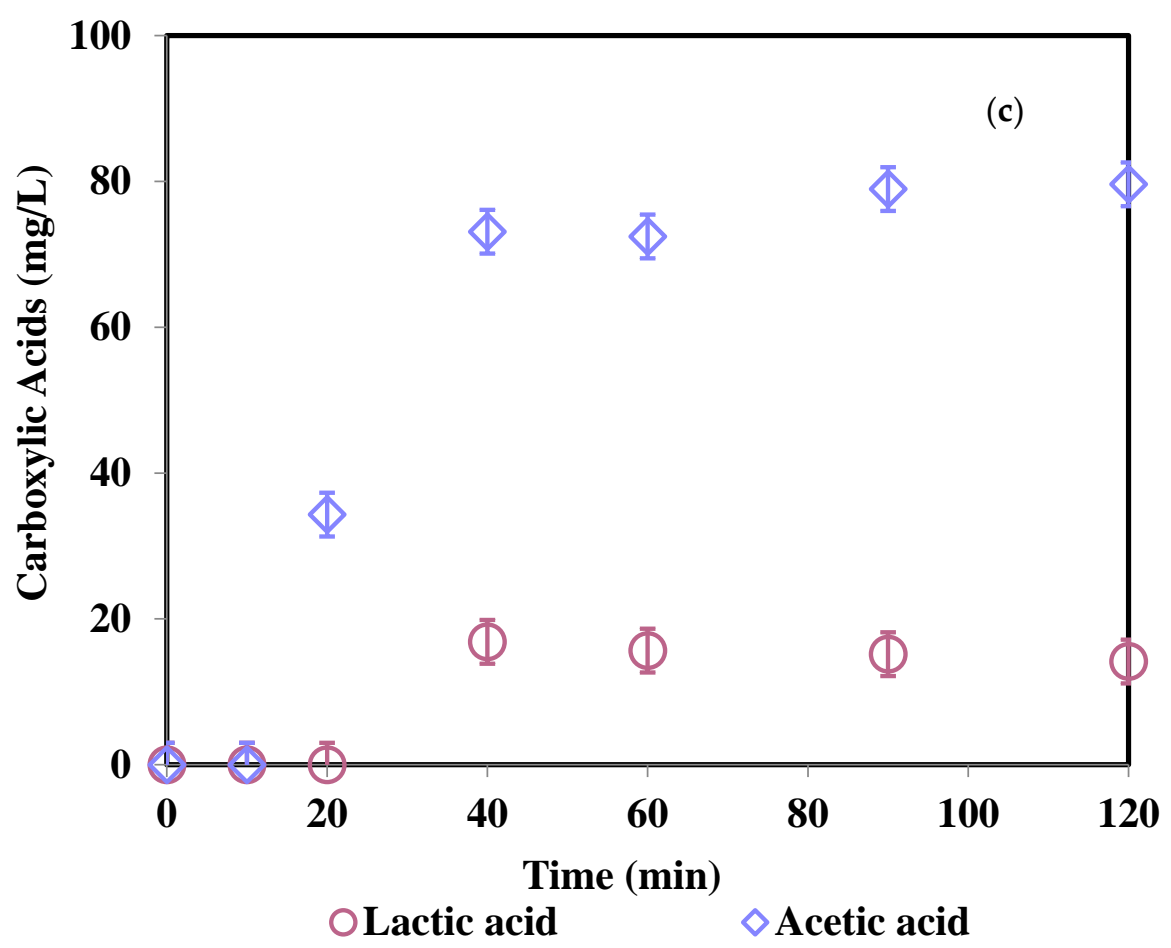

Figure 7. Changes in IPR and DOC (a), hydroquinone (b) and carboxylic acids (c) concentrations during ZVI/PS treatment. $\mathrm{IPR}=10 \mathrm{mg} / \mathrm{L} ; \mathrm{PS}=2.50 \mathrm{mM} ; \mathrm{ZVI}=1 \mathrm{~g} / \mathrm{L} ; \mathrm{pH}=3.0$.

Identification IPR degradation products during photochemical treatment were also carried out by HPLC. Figure S1 in the Supplementary Materials Section depicts changes in IPR and DOC (a), 2,4-DCA (b), and carboxylic acids (c) concentrations during UV$\mathrm{C} / \mathrm{PS}$ (PS = $0.30 \mathrm{mM}$; $\mathrm{pH}=6.2$ ) treatment of $10 \mathrm{mg} / \mathrm{L}$ IPR in DW. From Figure S1 (see Supplementary Materials section) it is evident that UV-C/PS treatment was effective both in terms of IPR and mineralization resulting in complete IPR and 78\% DOC removal after 120 min of UV-C/PS treatment. As seen in Figure S1, in the first 2 min of the IPR treatment with UV-C/PS, rapid 2,4-DCA formation was evident, most likely as a result of C-N bond cleavage. 2,4-DCA disappeared after $20 \mathrm{~min}$ of photochemical treatment. 2,4-DCA formation as one of the most common degradation intermediates of IPR degradation was reported previously in related work $[64,65]$. With the progress of photochemical treatment, hydroquinone (HQ), as one of the most common hydroxylated addition intermediates of aromatic organics, could be quantified at $\mathrm{t}=20 \mathrm{~min}$ and $\mathrm{t}=60 \mathrm{~min}$ as $0.050 \mathrm{mg} / \mathrm{L}$ and $0.064 \mathrm{mg} / \mathrm{L}$, respectively. HQ disappeared after 120 of min UV-C/PS treatment. Acetic and formic acid could be detected as the low molecule weight organic acid end products.

Figure S2 in the Supplementary Materials section shows changes in normalized IPR (a) and DOC (b) concentrations during the ZVA/PS (PS = $2.50 \mathrm{mM} ; \mathrm{pH}=3.0$ ) treatment of $10 \mathrm{mg} / \mathrm{L}$ IPR in DW. The insert in Figure S2a displays PS consumption (\%) during the ZVA/PS treatment of $10 \mathrm{mg} / \mathrm{L}$ IPR in DW. From Figure S2 it is evident that for the first 60 min ZVA/PS treatment, IPR removal was very slow, and only $12 \%$ IPR removal was achieved together with $25 \%$ PS consumption. With the progress of the treatment, IPR removal continued and reached $65 \%$ after 120 min of treatment together with $33 \%$ PS consumption and poor mineralization. The observed poor PS consumption (33\%) during 120 min of the ZVA/PS treatment of IPR can be explained by considering that IPR degradation was attributed not only to $\mathrm{SO}_{4}{ }^{\bullet-}$ but also to $\mathrm{HO}^{\bullet}$ derived from the reaction of $\mathrm{H}_{2} \mathrm{O}$ with $\mathrm{SO}_{4}{ }^{\bullet-}$ as well as single electron transfer from $\mathrm{ZVA}$ to $\mathrm{O}_{2}$ [65]. However, due to the lower diffusion rate of $\mathrm{O}_{2}$, whether $\mathrm{O}_{2}$ was involved in the reaction depended upon the degree of ZVA corrosion [55]. 
Identification of the above-mentioned oxidation intermediates was also investigated for the ZVA/PS treatment of IPR, however, none of them could be detected.

\subsection{Experiments in Simulated Tertiary Wastewater}

In order to elucidate the oxidation of IPR in a more complex effluent matrix by UV-C and zero-valent metal activated PS (UV-C/PS, ZVI/PS ZVA/PS treatments), additional experiments were conducted in a wastewater sample mimicking tertiary treated urban wastewater (called SWW herein). In addition, DOC removals were also investigated to study the fate of organic matter originating from IPR and its degradation products. Figure 8 presents changes in normalized IPR (a) and DOC (b) abatements through UV$\mathrm{C} / \mathrm{PS}$ (PS $=0.09 \mathrm{mM}$ ) treatments for $2 \mathrm{mg} / \mathrm{L}$ IPR-spiked SWW. The removal of IPR with UV-C/PS treatment was complete after $80 \mathrm{~min}$, whereas DOC removal was limited to only $24 \%$ after $120 \mathrm{~min}$ treatment. Apparently, UV-C/PS (PS = $0.09 \mathrm{mM}$ ) treatment was very sensitive to the SWW components and hence not capable of efficient DOC removal in more a complex matrix compared to DW. The ingredients of SWW (inorganic ions, organic matter) might compete with PS for UV-C light absorption, eventually leading to fewer available photons to generate $\mathrm{SO}_{4}{ }^{\bullet-}$ [66].

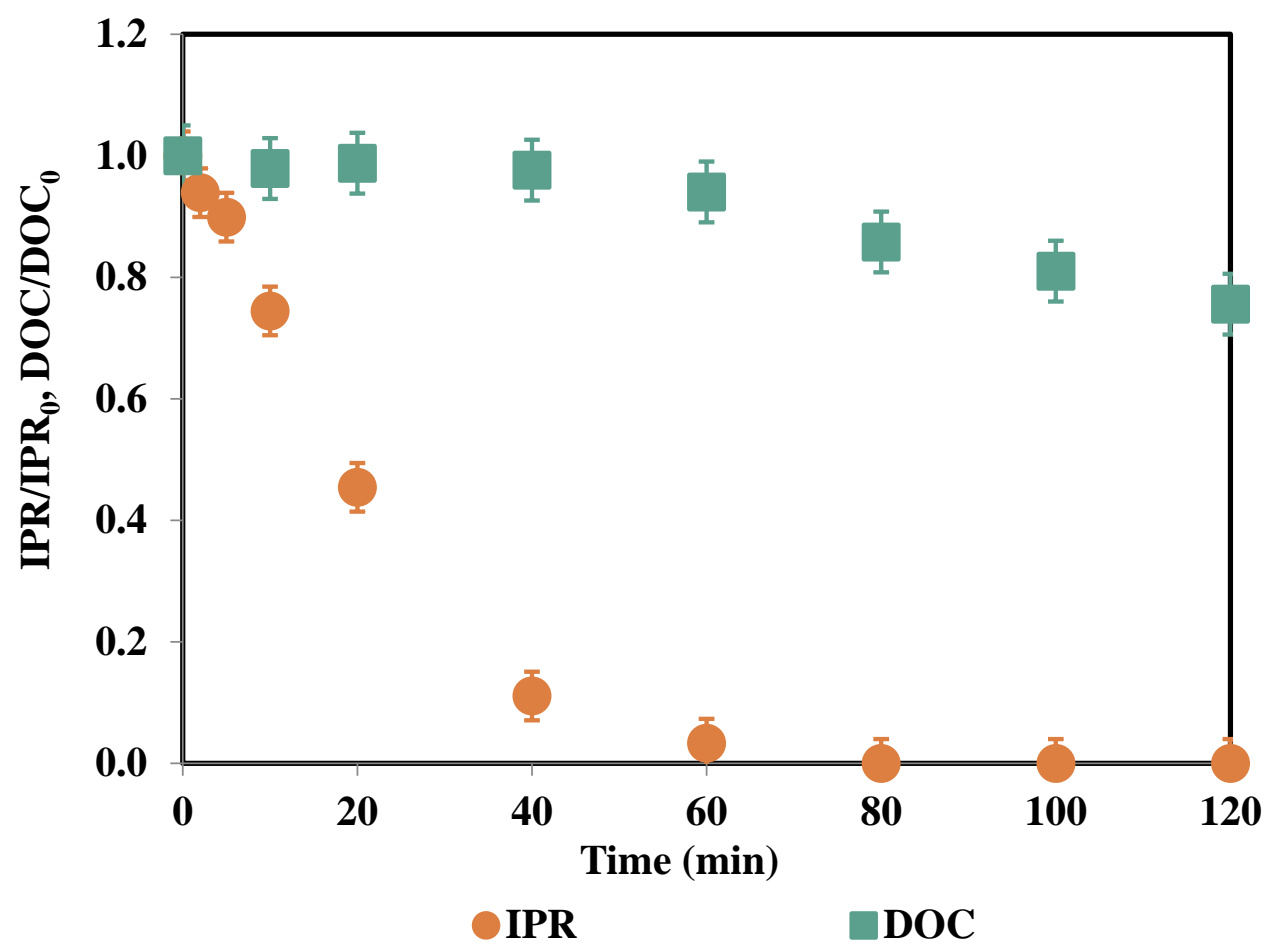

Figure 8. Changes in normalized IPR and DOC during UV-C/PS treatments in SWW. IPR $=2 \mathrm{mg} / \mathrm{L}$; $\mathrm{PS}=0.09 \mathrm{mM} ; \mathrm{DOC}=11.4 \mathrm{mg} / \mathrm{L} ; \mathrm{UV}-\mathrm{C}$ intensity $=0.5 \mathrm{~W} / \mathrm{L} ; \mathrm{pH}=6.8$ (the $\mathrm{pH}$ of SWW).

Figure 9 shows changes in normalized IPR and DOC values by ZVI/PS (PS = $1.50 \mathrm{mM}$ ) treatment at pH 3.0 with $2 \mathrm{mg} / \mathrm{L} \mathrm{IPR} \mathrm{in} \mathrm{SWW} \mathrm{(see} \mathrm{Table} \mathrm{S6} \mathrm{for} \mathrm{more} \mathrm{details).} \mathrm{From} \mathrm{Figure} \mathrm{9,}$ it is evident that IPR was completely removed after $20 \mathrm{~min}$ of ZVI/PS treatment together with $30 \%$ of DOC. Beyond this treatment time, no further DOC removal was observed. As seen in Figure 9, prolonged ZVI/PS treatment led to only $40 \%$ DOC reduction after $120 \mathrm{~min}$. 


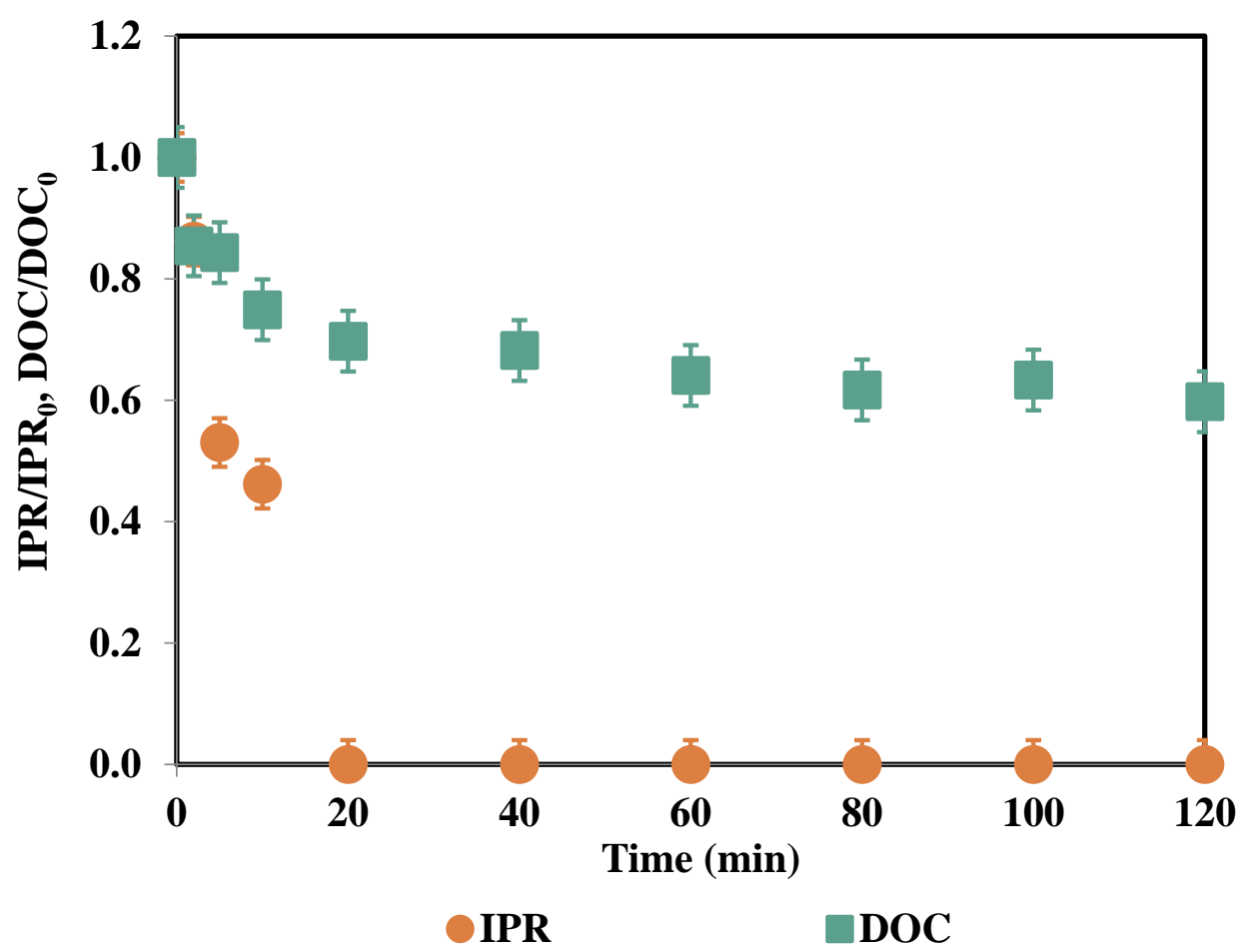

Figure 9. Changes in normalized IPR and DOC during ZVI/PS treatments in SWW. IPR $=2 \mathrm{mg} / \mathrm{L}$; $\mathrm{DOC}=11.4 \mathrm{mg} / \mathrm{L} ; \mathrm{PS}=1.50 \mathrm{mM} ; \mathrm{ZVI}=1 \mathrm{~g} / \mathrm{L}, \mathrm{pH}=3.0$.

Experiments in SWW indicated that complete IPR removal was achieved only after 120 min of ZVA/PS treatment. Figure 10 shows changes in normalized IPR and DOC values with ZVA/PS (PS = $1.50 \mathrm{mM}$; $\mathrm{pH}=3.0$ ) for $2 \mathrm{mg} / \mathrm{L}$ IPR treatment in SWW. From Figure 10, it is evident that no IPR removal occurred during the $120 \mathrm{~min}$ of ZVA/PS treatment of the SWW spiked with $2 \mathrm{mg} / \mathrm{L}$ IPR, while at the initial PS concentration of $0.50 \mathrm{mM}$, complete IPR removal was obtained in DW after $120 \mathrm{~min}$. This observation could be ascribed to the complexity of SWW (the presence of various inorganic and organic compounds) compared to DW [51]. The inhibition of IPR removal in SWW was stronger during ZVA/PS treatment compared to ZVI/PS treatment [51,67]. This observation could be attributed to the following: ZVA is more active than ZVI and hence more readily undergoes redox reactions. This higher reactivity of ZVA means lower selectivity so that in a complex wastewater matrix/in the presence of a variety of organic/inorganic constituents, the more reactive oxidant ZVA will not be used efficiently for the removal of the target pollutant and its degradation products. Moreover, when Fe is involved in redox reactions, additional removal mechanisms could play a role in the reaction solution $[32,56,67]$; in other words, other types of reaction routes are possible. Fe has two oxidation states$\mathrm{Fe}(\mathrm{II})$ and $\mathrm{Fe}(\mathrm{III})$ - that can undergo a series of redox (Fenton and Fenton-like oxidation) and complexation reactions with the SWW constituents. For instance, Fe complexation of iprodione's transformation products could enhance their oxidation by changing the solubility and availability of these substrates towards active oxidants $[50,57,67]$. In this way, the removal of iprodione and its organic carbon content would be more effective with ZVI. It should also be noted here that ZVA is more active at a very acidic $\mathrm{pH}(=1.5)$; however, very acidic $\mathrm{pH}$ values are not realistic conditions for wastewater treatment. At $\mathrm{pH}=3.0$, which was selected as the reaction $\mathrm{pH}$ for heterogeneous catalytic treatment in SWW, its performance is expected to decrease sharply. 


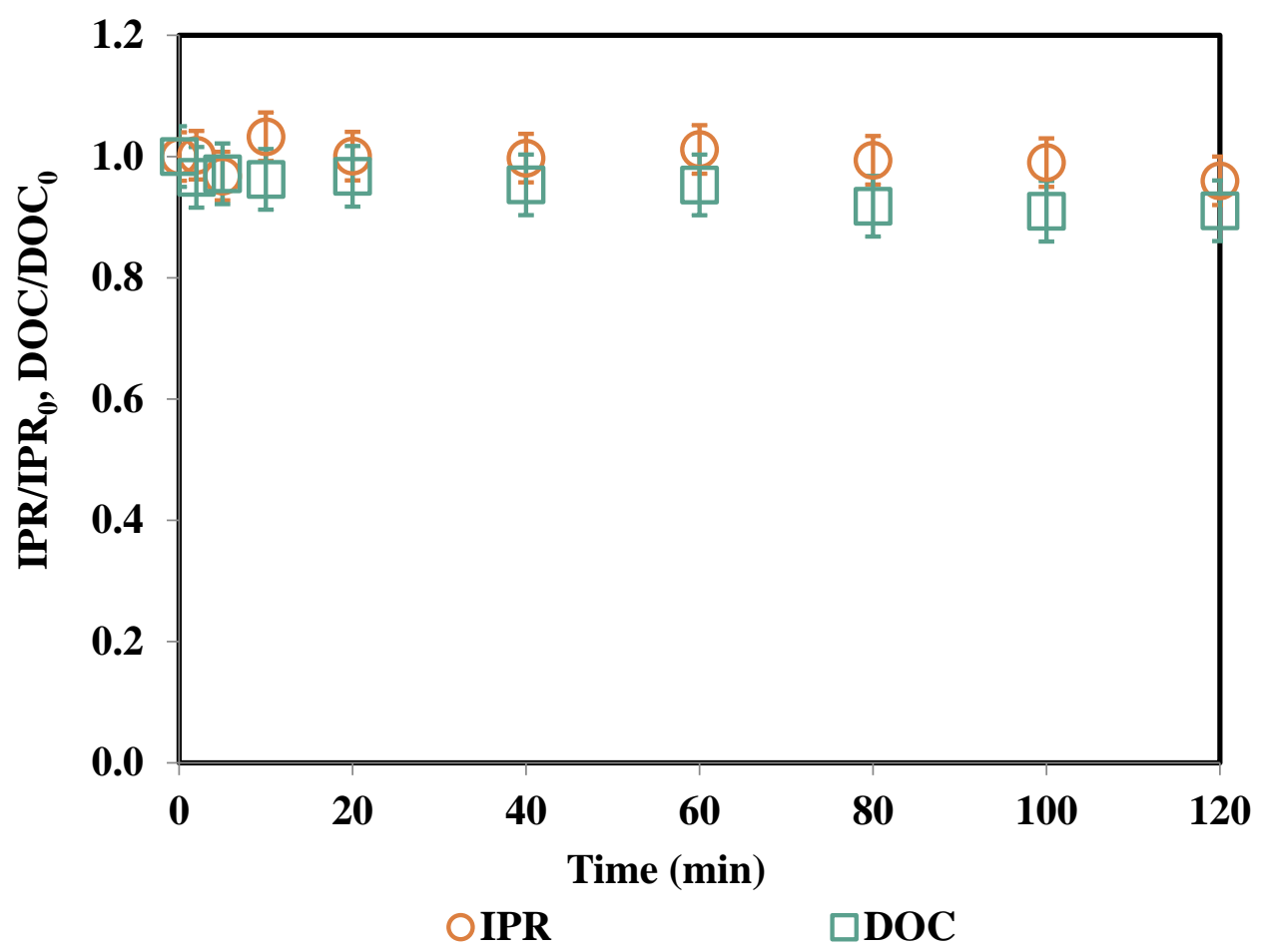

Figure 10. Changes in normalized IPR and DOC during ZVA/PS treatments in SWW. IPR $=2 \mathrm{mg} / \mathrm{L}$; $\mathrm{DOC}=11.96 \mathrm{mg} / \mathrm{L} ; \mathrm{PS}=1.50 \mathrm{mM} ; \mathrm{ZVA}=1 \mathrm{~g} / \mathrm{L}, \mathrm{pH}=3.0$.

Changes in normalized DOC values IPR-spiked SWW were also followed during $120 \mathrm{~min}$ ZVA/PS treatment at $\mathrm{pH} 3.0$ (see Table S7 for more details). In former related work [35], it was demonstrated that the presence of organic and inorganic compounds in wastewater samples such as humic acid (a major dissolved organic matter component in water/wastewater samples), had an inhibitory effect on the performance of the ZVA/PS oxidation system such that no iopamidol removal was observed during ZVA/PS treatment in the wastewater sample [35]. As seen in Figure 10, practically no change in normalized DOC was observed (9\%), indicating that the ingredients present in SWW might inhibit the oxidation process.

\section{Conclusions}

PS activation methods have recently gained an immense interest in micropollutant removal using sulfate-radical based advanced oxidation processes. In the present study, the degradation of IPR, a once commercially important fungicide identified as a potential carcinogen/endocrine disrupting compound and hence banned via regulation, was comparatively investigated employing one homogenous photochemical and two heterogeneous catalytic oxidation processes, namely UV-C/PS and ZVI/PS-ZVA/PS treatments, respectively. A series of treatability experiments were first y conducted at varying PS concentrations and $\mathrm{pH}$ values to examine the effect of these critical parameters on IPR removal in pure water. Moreover, degradation products of IPR were quantified in order to comparatively examine the reaction routes/mechanisms of the UV-C/PS, ZVI/PS and ZVA/PS treatment processes. IPR removal was also examined in simulated tertiary treated urban wastewater (SWW) under specific reaction conditions to elucidate the performance of the PS-activated oxidation systems in a real wastewater environment. UV-C /PS (PS $=0.09 \mathrm{mM}$; $\mathrm{pH}=6.8$ ) treatment of IPR in SWW resulted in complete IPR (in $80 \mathrm{~min}$ ) and $24 \%$ DOC removal after $120 \mathrm{~min}$, whereas $\mathrm{ZVI} / \mathrm{PS}$ ( $\mathrm{PS}=1.50 \mathrm{mM} ; \mathrm{pH}=3.0$ ) treatment exhibited faster IPR removal (in $20 \mathrm{~min}$ ) together with 40\% DOC removal after $120 \mathrm{~min}$ in SWW, revealing that the photochemical treatment process was more sensitive to the complex effluent matrix. 
Neither IPR removal nor DOC removals were obtained during ZVA/PS treatment in SWW, indicating that the presence of various organic and inorganic compounds in SWW seriously hindered and inhibited IPR removal with the more active/reactive ZVA/PS treatment system. From the experimental results it, was evident that those treatment processes showing superior treatment performance in pure water (DW), could result in a relatively poor treatment performance when applied in a simulated, complex wastewater matrix (SWW) due to their high reactivity (ZVA/PS), selectivity, and/or sensitivity (UV-C/PS). Considering the experimental findings of this study, the ZVI/PS treatment process may be offered as a more feasible treatment option for the efficient removal of industrial micropollutants found in water or wastewater. However, the economic feasibility and ecotoxicological safety of this heterogeneous iron-based catalytic treatment system should be further investigated in more detail before real-scale application could be envisioned.

Supplementary Materials: The following are available online at https:/ / www.mdpi.com/article/ 10.3390/w13121679/s1: Figure S1: Changes in IPR and DOC (a), 2,4-DCA (b) and carboxylic acids (c) concentrations during UV-C/PS treatment of IPR in DW. IPR $=10 \mathrm{mg} / \mathrm{L}$; PS $=0.30 \mathrm{mM}$; DOC of $10 \mathrm{mg} / \mathrm{L} \mathrm{IPR}=4.3 \mathrm{mg} / \mathrm{L} ; \mathrm{UV}-\mathrm{C}$ intensity $=0.5 \mathrm{~W} / \mathrm{L} ; \mathrm{pH}=6.2$. Figure $\mathrm{S} 1$ (a) insert gives the calculated PS consumptions (\%) during UV-C/PS treatment of $10 \mathrm{mg} / \mathrm{L}$ IPR in DW. Figure S2: Changes in normalized IPR (a) and DOC (b) values during ZVA/PS treatment in DW. IPR = $10 \mathrm{mg} / \mathrm{L}$; $\mathrm{PS}=2.50 \mathrm{mM}$; DOC for $10 \mathrm{mg} / \mathrm{L} \mathrm{IPR}=4.3 \mathrm{mg} / \mathrm{L} ; \mathrm{ZVA}=1 \mathrm{~g} / \mathrm{L} ; \mathrm{pH}=3.0$. Figure S2 (a) insert indicates the calculated PS consumptions (\%) during ZVA/PS treatment of $10 \mathrm{mg} / \mathrm{L} \mathrm{IPR} \mathrm{in} \mathrm{DW.} \mathrm{Table} \mathrm{S1:} \mathrm{IPR}$ removals obtained during mere ZVI treatment at an initial $\mathrm{pH}$ of 5.0, mere ZVA treatment at an initial $\mathrm{pH}$ of 3.0 as well as mere PS treatment of IPR at $\mathrm{pH}=6.2$. IPR $=2 \mathrm{mg} / \mathrm{L} ; \mathrm{ZVI}=1 \mathrm{~g} / \mathrm{L} ; \mathrm{ZVA}=1 \mathrm{~g} / \mathrm{L}$; PS $=1.00 \mathrm{mM}$. Table S2: IPR removals obtained during ZVI/PS treatment in DW. IPR $=2 \mathrm{mg} / \mathrm{L}$; $\mathrm{ZVI}=1 \mathrm{~g} / \mathrm{L}$. Table S3: IPR removals obtained during ZVA $/ \mathrm{PS}$ treatments in DW. IPR $=2 \mathrm{mg} / \mathrm{L}$; $\mathrm{ZVA}=1 \mathrm{~g} / \mathrm{L}$. Table S4: IPR and DOC removals as well as PS consumptions obtained during ZVI/PS treatment in DW. IPR = $10 \mathrm{mg} / \mathrm{L} ; \mathrm{DOC}=4.3 \mathrm{mg} / \mathrm{L} ; \mathrm{PS}=2.50 \mathrm{mM} ; \mathrm{ZVI}=1 \mathrm{~g} / \mathrm{L} ; \mathrm{pH}=3.0$. Table S5: IPR and DOC removals as well as PS consumptions during ZVA $/ P S$ treatment in DW. IPR $=10 \mathrm{mg} / \mathrm{L}$; PS = $2.50 \mathrm{mM}$; DOC for $10 \mathrm{mg} / \mathrm{L} \mathrm{IPR}=4.3 \mathrm{mg} / \mathrm{L} ; \mathrm{ZVA}=1 \mathrm{~g} / \mathrm{L} ; \mathrm{pH}=3.0$, Table S6: IPR and DOC removals as well as PS consumptions during ZVI/PS treatments in SWW. IPR = $2 \mathrm{mg} / \mathrm{L}$; DOC = $11.4 \mathrm{mg} / \mathrm{L} ; \mathrm{PS}=1.50 \mathrm{mM} ; \mathrm{ZVI}=1 \mathrm{~g} / \mathrm{L}, \mathrm{pH}=3.0$. Table S7: IPR and DOC removals as well as PS consumptions during ZVA/PS treatments in SWW. IPR = $2 \mathrm{mg} / \mathrm{L} ; \mathrm{DOC}=11.96 \mathrm{mg} / \mathrm{L} ; \mathrm{PS}=1.50 \mathrm{mM}$; $\mathrm{ZVA}=1 \mathrm{~g} / \mathrm{L}, \mathrm{pH}=3.0$.

Author Contributions: Conceptualization, I.A.-A. and T.O.-H.; methodology, I.A.-A. and T.O.-H.; software, B.M.; validation, B.M. and O.-K.U.; formal analysis, O.-K.U. and I.A.-A.; investigation, I.A.-A.; resources, I.A.-A.; data curation, B.M. and O.-K.U.; writing-original draft preparation, B.M.; writing-review and editing, I.A.-A.; visualization, B.M.; supervision, I.A.-A.; project administration, I.A.-A.; funding acquisition, I.A.-A. All authors have read and agreed to the published version of the manuscript.

Funding: This research was funded by the Istanbul Technical University under Grant Nr. MDK-201942052.

Institutional Review Board Statement: Not applicable.

Informed Consent Statement: Not applicable.

Data Availability Statement: The data presented in this study are available on request from the corresponding author.

Conflicts of Interest: The authors declare no conflict of interest.

\section{References}

1. Shimizu, T. Studies on the Use of Hydantoin-Related Compounds as Slow Release Fertilizers. Soil Sci. Plant Nutr. 1986, 32, 373-382. [CrossRef]

2. Belafdal, O.; Bergon, M.; Calmon, J.P. Mechanism of hydantoin ring opening in iprodione in aqueous media. Pestic. Sci. 1986, 17, 335-342. [CrossRef]

3. Andrioli, N.B.; Chaufan, G. Dose-independent genotoxic response in A549 cell line exposed to fungicide Iprodione. Arch. Toxicol. 2021, 95, 1071-1079. [CrossRef] 
4. Wei, Y.; Meng, Y.; Huang, Y.; Liu, Z.; Zhong, K.; Ma, J.; Zhang, W.; Li, Y.; Lu, H. Development toxicity and cardiotoxicity in zebrafish from exposure to iprodione. Chemosphere 2021, 263, 127860. [CrossRef]

5. Derbalah, A.; Nakatani, N.; Sakugawa, H. Distribution, seasonal pattern, flux and contamination source of pesticides and nonylphenol residues in Kurose River water, Higashi-Hiroshima, Japan. Geochem. J. 2003, 37, 217-232. [CrossRef]

6. Sequinatto, L.; Reichert, J.M.; Dos Santos, D.R.; Reinert, D.J.; Copetti, A.C.C. Occurrence of agrochemicals in surface waters of shallow soils and steep slopes cropped to tobacco. Quimica Nova 2013, 36, 768-772. [CrossRef]

7. Garbin, J.R.; Milori, D.; Simões, M.L.; da Silva, W.T.; Neto, L.M. Influence of humic substances on the photolysis of aqueous pesticide residues. Chemosphere 2007, 66, 1692-1698. [CrossRef] [PubMed]

8. Zhang, M.; Wang, W.; Zhang, Y.; Teng, Y.; Xu, Z. Effects of fungicide iprodione and nitrification inhibitor 3, 4-dimethylpyrazole phosphate on soil enzyme and bacterial properties. Sci. Total Environ. 2017, 599-600, 254-263. [CrossRef] [PubMed]

9. Sauret-Szczepanski, N.; Mirabel, P.; Wortham, H. Development of an SPME-GC-MS/MS method for the determination of pesticides in rainwater: Laboratory and field experiments. Environ. Pollut. 2006, 139, 133-142. [CrossRef]

10. Bernardes, P.M.; Andrade-Vieira, L.F.; Aragão, F.B.; Ferreira, A.; Ferreira, M.F.D.S. Toxicological effects of comercial formulations of fungicides based on procymidone and iprodione in seedlings and root tip cells of Allium cepa. Environ. Sci. Pollut. Res. 2019, 26, 21013-21021. [CrossRef] [PubMed]

11. Radice, S.; Ferraris, M.; Marabini, L.; Grande, S.; Chiesara, E. Effect of iprodione, a dicarboximide fungicide, on primary cultured rainbow trout (Oncorhynchus mykiss) hepatocytes. Aquat. Toxicol. 2001, 54, 51-58. [CrossRef]

12. Blystone, C.R.; Lambright, C.S.; Furr, J.; Wilson, V.S.; Grayjr, L.E., Jr. Iprodione delays male rat pubertal development, reduces serum testosterone levels, and decreases ex vivo testicular testosterone production. Toxicol. Lett. 2007, 174, 74-81. [CrossRef]

13. Dabrowski, J.M.; Shadung, J.M.; Wepener, V. Prioritizing agricultural pesticides used in South Africa based on their environmental mobility and potential human health effects. Environ. Int. 2014, 62, 31-40. [CrossRef] [PubMed]

14. European Commission (EC). Regulation EU 2091 Concerning the Non-Renewal of Approval of the Active Substance Iprodione, in Accordance with Regulation (EC) No 1107/2009 of the European Parliament and of the Council Concerning the Placing of Plant Protection Products on the Market, and Amending Commission Implementing Regulation (EU) No 540/2011; Official Journal of the European Union: Brussels, Belgium, 2017; pp. 25-27.

15. Wang, J.; Zhuan, R. Degradation of antibiotics by advanced oxidation processes: An overview. Sci. Total Environ. 2020, 701, 135023. [CrossRef] [PubMed]

16. Yang, Q.; Ma, Y.; Chen, F.; Yao, F.; Sun, J.; Wang, S.; Yi, K.; Hou, L.; Li, X.; Wang, D. Recent advances in photo-activated sulfate radical-advanced oxidation process (SR-AOP) for refractory organic pollutants removal in water. Chem. Eng. J. 2019, 378, 122149. [CrossRef]

17. Wang, J.L.; Xu, L.J. Advanced Oxidation Processes for Wastewater Treatment: Formation of Hydroxyl Radical and Application. Crit. Rev. Environ. Sci. Technol. 2012, 42, 251-325. [CrossRef]

18. Wacławek, S.; Lutze, H.V.; Grübel, K.; Padil, V.V.T.; Černík, M.; Dionysiou, D.D. Chemistry of persulfates in water and wastewater treatment: A review. Chem. Eng. J. 2017, 330, 44-62. [CrossRef]

19. Dewil, R.; Mantzavinos, D.; Poulios, I.; Rodrigo, M.A. New perspectives for Advanced Oxidation Processes. J. Environ. Manag. 2017, 195, 93-99. [CrossRef]

20. Cuerda-Correa, E.M.; Alexandre-Franco, M.F.; Fernández-González, C. Advanced Oxidation Processes for the Removal of Antibiotics from Water: An Overview. Water 2020, 12, 102. [CrossRef]

21. Xiao, S.; Cheng, M.; Zhong, H.; Liu, Z.; Liu, Y.; Yang, X.; Liang, Q. Iron-mediated activation of persulfate and peroxymonosulfate in both homogeneous and heterogeneous ways: A review. Chem. Eng. J. 2020, 384, 123265. [CrossRef]

22. Chen, W.-S.; Su, Y.-C. Removal of dinitrotoluenes in wastewater by sono-activated persulfate. Ultrason. Sonochem. 2012, 19, 921-927. [CrossRef] [PubMed]

23. Liang, C.; Su, H.-W. Identification of Sulfate and Hydroxyl Radicals in Thermally Activated Persulfate. Ind. Eng. Chem. Res. 2009, 48, 5558-5562. [CrossRef]

24. Kolthoff, I.M.; Miller, I.K. The Chemistry of Persulfate. I. The Kinetics and Mechanism of the Decomposition of the Persulfate Ion in Aqueous Medium. J. Am. Chem. Soc. 1951, 73, 3055-3059. [CrossRef]

25. Buxton, G.V.; Greenstock, C.L.; Helman, W.P.; Ross, A.B. Critical Review of rate constants for reactions of hydrated electrons, hydrogen atoms and hydroxyl radicals $\left(\mathrm{OH} / \mathrm{O}^{-}\right.$in Aqueous Solution. J. Phys. Chem. Ref. Data 1988, 17, 513-886. [CrossRef]

26. Dogliotti, L.; Hayon, E. Flash photolysis of per[oxydi]sulfate ions in aqueous solutions. The sulfate and ozonide radical anions. $J$. Phys. Chem. 1967, 71, 2511-2516. [CrossRef]

27. Kim, C.; Ahn, J.-Y.; Kim, T.Y.; Shin, W.S.; Hwang, I. Activation of Persulfate by Nanosized Zero-Valent Iron (NZVI): Mechanisms and Transformation Products of NZVI. Environ. Sci. Technol. 2018, 52, 3625-3633. [CrossRef]

28. Pang, Y.; Zhou, Y.; Luo, K.; Zhang, Z.; Yue, R.; Li, X.; Lei, M. Activation of persulfate by stability-enhanced magnetic gra-phene oxide for the removal of 2,4-dichlorophenol. Sci. Total Environ. 2019, 707, 135656. [CrossRef]

29. Qian, L.; Liu, P.; Shao, S.; Wang, M.; Zhan, X.; Gao, S. An efficient graphene supported copper salen catalyst for the activation of persulfate to remove chlorophenols in aqueous solution. Chem. Eng. J. 2019, 360, 54-63. [CrossRef]

30. Wu, S.; He, H.; Li, X.; Yang, C.; Zeng, G.; Wu, B.; He, S.; Lu, L. Insights into atrazine degradation by persulfate activation using composite of nanoscale zero-valent iron and graphene: Performances and mechanisms. Chem. Eng. J. 2018, 341, 126-136. [CrossRef] 
31. Gao, Y.-Q.; Zhang, J.; Zhou, J.-Q.; Li, C.; Gao, N.-Y.; Yin, D.-Q. Persulfate activation by nano zero-valent iron for the degradation of metoprolol in water: Influencing factors, degradation pathways and toxicity analysis. RSC Adv. 2020, 10, 20991-20999. [CrossRef]

32. Nidheesh, P.; Khatri, J.; Singh, T.A.; Gandhimathi, R.; Ramesh, S. Review of zero-valent aluminium based water and wastewater treatment methods. Chemosphere 2018, 200, 621-631. [CrossRef] [PubMed]

33. Oh, S.-Y.; Kang, S.-G.; Chiu, P.C. Degradation of 2,4-dinitrotoluene by persulfate activated with zero-valent iron. Sci. Total Environ. 2010, 408, 3464-3468. [CrossRef] [PubMed]

34. Oh, S.-Y.; Kim, H.-W.; Park, J.-M.; Park, H.-S.; Yoon, C. Oxidation of polyvinyl alcohol by persulfate activated with heat, Fe ${ }^{2+}$, and zero-valent iron. J. Hazard. Mater. 2009, 168, 346-351. [CrossRef]

35. Arslan-Alaton, I.; Olmez-Hanci, T.; Korkmaz, G.; Sahin, C. Removal of iopamidol, an iodinated X-ray contrast medium, by zero-valent aluminum-activated $\mathrm{H}_{2} \mathrm{O}_{2}$ and $\mathrm{S}_{2} \mathrm{O}_{8}{ }^{2-}$. Chem. Eng. J. 2017, 318, 64-75. [CrossRef]

36. Montazeri, B.; Ucun, O.K.; Arslan-Alaton, I.; Olmez-Hanci, T. UV-C-activated persulfate oxidation of a commercially im-portant fungicide: Case study with iprodione in pure water and simulated tertiary treated urban wastewater. Environ. Sci. Pollut. Res. 2020. [CrossRef]

37. Karci, A.; Arslan-Alaton, I.; Bekbolet, M.; Ozhan, G.; Alpertunga, B. $\mathrm{H}_{2} \mathrm{O}_{2}$ /UV-C and Photo-Fenton treatment of a nonylphenol polyethoxylate in synthetic freshwater: Follow-up of degradation products, acute toxicity and genotoxicity. Chem. Eng. J. 2014, 241, 43-51. [CrossRef]

38. Ucun, O.K.; Montazeri, B.; Arslan-Alaton, I.; Olmez-Hanci, T. Degradation of 3,5-dichlorophenol by UV-C photolysis and UV-C-activated persulfate oxidation process in pure water and simulated tertiary treated urban wastewater. Environ. Technol. 2020, 2020, 1-12. [CrossRef]

39. Kreuger, J. Pesticides in stream water within an agricultural catchment in southern Sweden, 1990-1996. Sci. Total Environ. 1998, 216, 227-251. [CrossRef]

40. Stamatis, N.; Hela, D.; Konstantinou, I. Occurrence and removal of fungicides in municipal sewage treatment plant. J. Hazard. Mater. 2010, 175, 829-835. [CrossRef]

41. Bessergenev, V.; Mateus, M.; Morgado, I.; Hantusch, M.; Burkel, E. Photocatalytic reactor, CVD technology of its preparation and water purification from pharmaceutical drugs and agricultural pesticides. Chem. Eng. J. 2017, 312, 306-316. [CrossRef]

42. Lopez-Alvarez, B.; Villegas-Guzman, P.; Peñuela, G.A.; Torres-Palma, R.A. Degradation of a Toxic Mixture of the Pesticides Carbofuran and Iprodione by $\mathrm{UV} / \mathrm{H}_{2} \mathrm{O}_{2}$ : Evaluation of Parameters and Implications of the Degradation Pathways on the Synergistic Effects. Water Air Soil Pollut. 2016, 227, 1-13. [CrossRef]

43. Lassalle, Y.; Jellouli, H.; Ballerini, L.; Souissi, Y.; Nicol, É.; Bourcier, S.; Bouchonnet, S. Ultraviolet-vis degradation of iprodione and estimation of the acute toxicity of its photodegradation products. J. Chromatogr. A 2014, 1371, 146-153. [CrossRef]

44. Schwack, W.; Bourgeois, B.; Walker, F. Fungicides and photochemistry photodegradation of the dicarboximide fungicide iprodione. Chemosphere 1995, 31, 2993-3000. [CrossRef]

45. Hussain, I.; Zhang, Y.; Huang, S. Degradation of aniline with zero-valent iron as an activator of persulfate in aqueous solution. RSC Adv. 2014, 4, 3502-3511. [CrossRef]

46. Hussain, I.; Zhang, Y.; Huang, S.; Du, X. Degradation of $p$-chloroaniline by persulfate activated with zero-valent iron. Chem. Eng. J. 2012, 203, 269-276. [CrossRef]

47. Messele, S.A.; Bengoa, C.; Stüber, F.E.; Giralt, J.; Fortuny, A.; Fabregat, A.; Font, J. Enhanced Degradation of Phenol by a Fenton-Like System (Fe/EDTA/ $\mathrm{H}_{2} \mathrm{O}_{2}$ ) at Circumneutral pH. Catalysts 2019, 9, 474. [CrossRef]

48. International Organization for Standardization (ISO). Water Quality-Application of Inductively Coupled Plasma Mass Spectrometry (ICP-MS)_Part 2: Determination of 62 Elements; 17294-2; International Organization for Standardization: Geneva, Switzerland, 2003.

49. Villegas, E.; Pomeranz, Y.; Shellenberger, J. Colorimetric determination of persulfate with alcian blue. Anal. Chim. Acta 1963, 29, 145-148. [CrossRef]

50. Bokare, A.D.; Choi, W. Zero-valent aluminum for oxidative degradation of aqueous organic pollutants. Environ. Sci. Technol. 2009, 43, 7130-7135. [CrossRef]

51. Arslan-Alaton, I.; Olmez-Hanci, T.; Ozturk, T. Effect of inorganic and organic solutes on zero-valent aluminum-activated hydrogen peroxide and persulfate oxidation of bisphenol A. Environ. Sci. Pollut. Res. 2018, 25, 34938-34949. [CrossRef] [PubMed]

52. Zhao, L.; Ji, Y.; Kong, D.; Lu, J.; Zhou, Q.; Yin, X. Simultaneous removal of bisphenol A and phosphate in zero-valent iron activated persulfate oxidation process. Chem. Eng. J. 2016, 303, 458-466. [CrossRef]

53. Arslan-Alaton, I.; Olmez-Hanci, T.; Dogan, M.; Ozturk, T. Zero-valent aluminum-mediated degradation of Bisphenol A in the presence of common oxidants. Water Sci. Technol. 2017, 76, 2455-2464. [CrossRef]

54. Temiz, K.; Olmez-Hanci, T.; Arslan-Alaton, I. Zero-valent iron-activated persulfate oxidation of a commercial alkyl phenol polyethoxylate. Environ. Technol. 2016, 37, 1-11. [CrossRef]

55. Ren, T.; Yang, S.; Jiang, Y.; Sun, X.; Zhang, Y. Enhancing surface corrosion of zero-valent aluminum (ZVAl) and electron transfer process for the degradation of trichloroethylene with the presence of persulfate. Chem. Eng. J. 2018, 348, 350-360. [CrossRef]

56. Pignatello, J.J.; Oliveros, E.; Mackay, A. Advanced Oxidation Processes for Organic Contaminant Destruction Based on the Fenton Reaction and Related Chemistry. Crit. Rev. Environ. Sci. Technol. 2006, 36, 1-84. [CrossRef]

57. Ni Soon, A.; Hameed, B. Heterogeneous catalytic treatment of synthetic dyes in aqueous media using Fenton and photo-assisted Fenton process. Desalination 2011, 269, 1-16. [CrossRef] 
58. Barzegar, G.; Jorfi, S.; Zarezade, V.; Khatebasreh, M.; Mehdipour, F.; Ghanbari, F. 4-Chlorophenol degradation using ultrasound/peroxymonosulfate/nanoscale zero valent iron: Reusability, identification of degradation intermediates and potential application for real wastewater. Chemosphere 2018, 201, 370-379. [CrossRef] [PubMed]

59. Wei, X.; Gao, N.; Li, C.; Deng, Y.; Zhou, S.; Li, L. Zero-valent iron (ZVI) activation of persulfate (PS) for oxidation of bentazon in water. Chem. Eng. J. 2016, 285, 660-670. [CrossRef]

60. Zhao, J.; Zhang, Y.; Quan, X.; Chen, S. Enhanced oxidation of 4-chlorophenol using sulfate radicals generated from zero-valent iron and peroxydisulfate at ambient temperature. Sep. Purif. Technol. 2010, 71, 302-307. [CrossRef]

61. Zhang, H.; Cao, B.; Liu, W.; Lin, K.; Feng, J. Oxidative removal of acetaminophen using zero valent aluminum-acid system: Efficacy, influencing factors, and reaction mechanism. J. Environ. Sci. 2012, 24, 314-319. [CrossRef]

62. Liu, W.; Zhang, H.; Cao, B.; Lin, K.; Gan, J. Oxidative removal of bisphenol A using zero valent aluminum-acid system. Water Res. 2011, 45, 1872-1878. [CrossRef]

63. Li, H.; Wan, J.; Ma, Y.; Huang, M.; Wang, Y.; Chen, Y. New insights into the role of zero-valent iron surface oxidation layers in persulfate oxidation of dibutyl phthalate solutions. Chem. Eng. J. 2014, 250, 137-147. [CrossRef]

64. Wittke, K.; Hajimiragha, H.; Dunemann, L.; Begerow, J. Determination of dichloroanilines in human urine by GC-MS, GC-MS-MS, and GC-ECD as markers of low-level pesticide exposure. J. Chromatogr. B Biomed. Sci. Appl. 2001, 755, 215-228. [CrossRef]

65. Turci, R.; Barisano, A.; Balducci, C.; Colosio, C.; Minoia, C. Determination of dichloroanilines in human urine by gas chromatography/mass spectrometry: Validation protocol and establishment of Reference Values in a population group living in central Italy. Rapid Commun. Mass Spectrom. 2006, 20, 2621-2625. [CrossRef]

66. Fu, Y.; Gao, X.; Geng, J.; Li, S.; Wu, G.; Ren, H. Degradation of three nonsteroidal anti-inflammatory drugs by UV/persulfate: Degradation mechanisms, efficiency in effluents disposal. Chem. Eng. J. 2019, 356, 1032-1041. [CrossRef]

67. Luo, H.; Zeng, Y.; He, D.; Pan, X. Application of iron-based materials in heterogeneous advanced oxidation processes for wastewater treatment: A review. Chem. Eng. J. 2021, 407, 127191. [CrossRef] 